\title{
The Regal Ships and Divine Kingdom
}

\section{Carl Olof Cederlund}

\begin{abstract}
This paper deals with the use of old, preserved ships as ship symbols in society. Emanating from this is also a special treatment of the projection of the symbolism of the "regal ship" in Swedish society since the 17th century. "Regal ship" was a denomination, during the 17th century, of big, sailing warships in the Swedish navy. In this connection is also traced and discussed the ideology adhering to the symbolic expressions around the "regal ships" in past and present society.
\end{abstract}

Carl Olof Cederlund, Department of Archaeology, Stockholm University, S-106 91 Stockholm, Sweden.

The "-isms" are ripples on the surface of ideology

"Thursday the 20th of August in the year 1959 at $8.13 \mathrm{P} \mathrm{M}$ goes to history. While the August moon just comes up over the silhouette of Three Crown Mill, while Jussi Björling sings "Sverige" on the stage of the Gröna Lund amusement park and a churchbell strikes 12 mighty strokes somewhere in the south of the city of Stockholm, this historical event is taking place, an event which again directs the eyes of the world to Sweden and which has attracted leading press media and radio stations from the whole planet Earth to Stockholm"

This is the opening of an article by the young journalist Björn Fredrik Höijer in the Swedish evening paper Kvällsposten on the 21 st of August 1959. What kind of event could have inspired such a lyrical approach as in this article, with such strong nationalistic tones? As a matter of fact, the article has the title "Wasa sails again for the first time in 330 years" and its text is a description of the first brief lift in 1959 of the warship Vasa which sank in Stockholm harbour in 1628 (the salvage was staged as the successive lifting of the big hull towards more shallow waters from where it finally was raised to the surface).

The song "Sverige," mentioned in the article, was originally intended to be the national anthem of Sweden and in some ways serves as one alongside the official national anthem. It was written by the poet Verner von Heidenstam and set to music by the composer Wilhelm Stenhammar in the period of nationalism and romanticism during the ending 19th century. Jussi Björling was one of the most famous Swedish singers of this century, nationally not least known for his performances of songs of national romanticism.

This was the first step toward salvaging the Vasa; it occured in the end of the $1950 \mathrm{~s}$ and led to the raising of the ship to the surface in April 1961. The part of the article cited here is an expression of evaluations which, together with similar ones, often appeared in connection with the salvaging of this old warship. A closer look at this phenomenon shows that these evaluations have not only appeared on this occasion. They have surfaced on many other similar occasions in relation to old and mighty ships, both before and after the event described here. They can also be connected with a pattern of evaluations that 
has existed for a long time. Let us start with an overview of old preserved ships in society.

\section{OLD, PRESERVED SHIPS AS A CULTURAL PHENOMENON}

Looking through history one can see the ship appearing as a strong symbol in many societies and in different periods of time. If one looks around the world of this century one can easily find a number of cases in which old ships have been taken care of, preserved, and exhibited because they are tokens or expressions of certain values in the society which displays them.

The preservation of many of the ships described here is due to marine archaeological, in some cases also land archaeological, investigations and modern conservation techniques. Many others are ships which have been preserved since they were in use, still afloat or in dry docks. In some cases the ships are modern-day replicas of ships which no longer exist but which are known from literary or iconographic sources. Let me make a short list of a few examples of such ships in roughly chronological order.

\section{Egypt}

The Ship of Cheops was found in a burial chamber at the Cheops pyramid in Egypt. The ship is dated to about $2500 \mathrm{BC}$. It is supposed to have been the funeral barge of Pharaoh Cheops, built to carry him to the next world. The $42 \mathrm{~m}$ long ship has been reconstructed and is now displayed in a museum near the pyramid (Brouwer 1985).

\section{Greece}

During the 1980 s a replica of a Hellenic Trireme, given the name Olympias, was built in Greece in cooperation with the Hellenic Navy, the Ministry of Cultural Affairs and Science, and the British Trireme Trust. The Trireme was a type of Hellenic warship propelled by many oars placed on three diffe- rent levels in the hull and with sails rigged on two masts. These ships were built with a heavy ram in the bow. No material remains of these 2000 year old vessels are known today. Their construction has been debated by scholars since the 18th century. One of the main aims of building the Trireme replica was "to recreate one of the major artefacts of Hellenic civilisation and a unique ship type of outstanding interest to naval historians and architects" (Morrison \& Coates 1989).

\section{Italy}

The Nemi Ships, two $70 \mathrm{~m}$ long vessels from the time of the emperor Caligula (12-41 AD), were uncovered during the draining of Lake Nemi near Rome, Italy in the 1920s and 1930s. The ships had been two big, floating leisure palaces probably built on the initiative of the emperor. The vessels were raised out of the lake and preserved as a national, Italian enterprise. A museum was built around them and the finds from them. The museum was burnt down during the Second World War (Svensk Uppslagsbok 1937).

\section{Norway}

Three Viking ships from the 9th and 10th centuries were excavated from grave mounds in central Norway in the late 19th and the early 20th century and exhibited in the Viking Ship Hall at Bygdöy. The most well known of the three ships are the Oseberg and the Gokstad ships, both supposed to have been the burial ships of chieftains or kings of Viking Age Norway. The ship from Oseberg from the 9th century, according to one theory, may have belonged to and become the burial ship of Queen Åsa. According to Snorre Sturlasson, she was the spouse of King Gudröd who governed parts of Norway in the middle of the 9th century AD. The Gokstad ship from the 10th century is supposed to have been a "ledung ship," a warship of the Viking Age. Several full-scale replicas have been built of this ship. One was designed by the Norwegian Magnus Andersen in 1893 and sailed over the 
Atlantic, first to New York and then to the World Exhibition in Chicago which was the goal of the journey. The Viking ship replica was displayed at the exhibition. Later it was put on display in the Chicago Museum of National History, where the ship is still exhibited (Christensen 1986).

Bygdöy, at which the Viking Ship Hall is situated, is a peninsula west of Oslo, the capital of Norway, and it was royal property during the medieval period. Just beside the Viking Ship Hall is Bygdöy royal demesne which is the summer residence of the royal family today. In the neighbourhood there are also Norwegian national shrines such as the Norsk Folkemuseum (Eng. Norwegian Folk Museum) and the National Maritime Museum of Norway (Svensk Uppslagsbok 1937).

\section{Denmark}

Five Viking ships dated to the 1lth century have been raised from the bottom of Roskilde Fjord and are exhibited in the Viking Ship Hall in the town of Roskilde. Of the five ships now reconstructed in the museum hall, two are warships and three are trading or transport ships of different types. The ships had originally been scuttled in the fjord as a base for a stone barrier protecting the town of Roskilde from seaborne enemies.

From the latter part of the 11th century, from which the ships date, to the 15 th century Roskilde was also the town of residence of the Danish kings. The cathedral of Roskilde is a Danish pantheon housing the graves of Danish kings and queens (Rieck \& CrumlinPedersen 1988; Svensk Uppslagsbok 1937). In the 1980 s several replicas were built especially of the trading ships from Skuldelev, with the main aim to widen the knowledge of the sailing capacity of these vessels. One replica of Skuldelev I, originally a seagoing vessel, was built in Norway and named Saga Siglar. It was taken on a successful circumnavigation of the globe by its designer the Norwegian Ragnar Thorseth in the 1980s (Thorseth 1986).

\section{Germany}

The Bremen Cog is the denomination of a cog ship found in and lifted out of the river Weser in Bremen harbour in 1962. After excavation and salvaging of the well-preserved hull, the $\operatorname{cog}$ was taken to the Deutsches Schiffarts-' museum in Bremerhaven. There it has been restored and is now undergoing conservation treatment in the museum under the eyes of the public (Fliedner 1962). The building-time of the Bremen cog has been dated to about 1380 .

The cog is a type of ship used by merchants in the Hanseatic League for several centuries. The Bremen cog has been defined as "the type of ship which during the two centuries from c. 1200 to 1400 played the major role in overseas trade in the northern European seas and was therefore the most important technical instrument in the economic, social and political rise of the Hanseatic League and the indvidual great Hanseatic cities" (Fliedner, 1962: 36).

\section{Spain, Italy and the USA}

Several replicas have been built of the ships of Columbus - the Sancta Maria, the Nina and the Pinta, for example in Spain and Italy. The first were built already in 1892 for the four hundred year anniversary of Columbus's first voyage over the Atlantic. The Santa Maria replica of that time was sailed over the Atlantic in 1893 for display at the World Columbian Exhibition in Chicago (Dudszus \& Henriot 1986; Smith 1988). Since then the crossing of the Atlantic has been repeated with other replicas of these ships.

\section{England}

The Mary Rose, a flagship in the navy of King Henry VIII, was built in 1509-1511 and foundered in the Solent just outside Portsmouth in 1545. The wreck of the ship was raised from the bottom in 1982 and is now exhibited in a special museum inside the Portsmouth Dockyard of the British Royal Navy (Rule 1982). 


\section{USA}

The Mayflower was a British trader which in 1620 came to play an important role in the emigration to the New World, bringing the pilgrims who established the first permanent colony in New England. A replica of the Mayflower was built 1955-1956 and sailed over the Atlantic in 1957. The modern Mayflower is since then on exhibit in Plymouth, Mass. (Baker 1958; Dudszus \& Henriot 1986).

\section{Sweden}

The Vasa, was a regal ship (Sw."regalskepp"), built in Stockholm in 1626-1628. It foundered on its maiden voyage in 1628 in Stockholm harbour. The ship was salvaged in 1961 and is now exhibited in the Vasa Museum in Stockholm after reconstruction and conservation (Franzén 1974). The newly opened Vasa Museum is situated at Djurgården, on royal property, in a dock of the former naval base there. The museum is situated near the Nordic Museum and the open-air museum Skansen which exhibit folk culture and national art of Sweden.

\section{Australia}

The Batavia was a Dutch East India-man, lost off the west coast of Australia in 1629. The wreck was located in 1963 at Morning Reef in the Wallabi group of islands. During the 1970 s an underwater excavation was performed at the site by the Western Australian Museum, Perth. A rich find material was retrieved, among other things wares and treasures on their way to the Far East to be used in the Dutch trade colony there. Also, over one third of the port side of the hull of the ship and part of the transom were located. These preserved parts of the ship's structure have been salvaged, conserved, and reconstructed and are now on display at the Western Australian Museum in Perth, as an exhibition of the Dutch East India Company, its shipbuilding, and extensive seafaring to and trade with the Far East (Green 1980).

\section{England}

The Victory is a warship in the Royal British Navy, known especially as the flagship of vice admiral Lord Nelson in the battle of Trafalgar in 1805. After having been paid off in 1835 the ship was selected as the permanent, and stationary, flagship of the commander in chief at Portsmouth naval base. In the 20 th century the ship was placed in a dry dock in Portsmouth Dockyard, restored and rerigged to her original state. On completion she was opened to the public, as a permanent memorial to Nelson, Trafalgar and to the British Navy (Kemp 1979).

\section{Sweden}

The Royal schooner "Amphion" was built for King Gustaf III of Sweden in Stockholm in 1778. The beautifully adorned vessel was intented as a leisure ship for archipelago cruising by the king, but it was also used as his staff ship in the war against Russia in 17881790. During the first half of the 19th century the ship was used as a staff vessel by the navy. In the latter part of the same century the vessel was used as a receiving ship. When it was scrapped in 1884 - 1885 the figure-head, the stern, the skylight, and most parts of the interior of the aft cabin of the ship, the royal beds, etc. were saved and stored. When the Swedish National Maritime Museum was planned and built in Stockholm in the 1930s the stern part of the Amphion was reconstructed with its original decorations in the Hall of Memory in the museum (Lenk 1938).

\section{USA}

The USS Constitution, one of the "six original frigates" authorized by the US Congress in 1794, is generally regarded by Americans as the most famous ship in the history of the US navy. She established her enduring reputation in the war against England in 1812 . The Constitution was condemned as unseaworthy in 1828 and it was recommended that she be broken up. In his poem "Old 
Ironsides" Oliver Wendell Holmes aroused public sentiment for the preservation of the old vessel. As far as possible the ship was restored to her original appearance.

After restoration in 1927-1931 she called at ninety ports in the USA and was visited by about 4,500,000 people. She is berthed in the Navy Yard in Boston where she was built (Kemp 1979).

\section{England}

The Great Britain was the first large iron ship, built as a transatlantic liner and the first to be screw-propelled. She was designed by Isambard Kingdom Brunel and launched at Bristol in 1843. After a period in the transatlantic traffic she was used as a cargo and passenger ship to Australia. Finally, after several decades in service, she was beached at Port Stanley, Falkland Islands. In 1970 she was placed on a pontoon, which was towed first to Montevideo and then to Bristol. There the Great Britain was successfully placed in the very dock in which she was built. She was restored to her original condition and rig - as a national monument and an example of iron shipbuilding in its earliest days (Kemp 1979).

\section{Denmark}

The frigate Jylland, launched in Copenhagen in 1860 , is a representative of the warships from this period propelled with both sail and steam. The ship took part and was damaged in the battle at Helgoland in 1864 in the war against Prussia and Austria - a war strongly influenced by and influencing Nordic nationalism at the time. Since 1960 the Jylland, which has been afloat since the 19th century, is under conservation in the town of Ebeltoft in Jutland, Denmark (Steensen Steen 1961).

\section{USA}

The Monitor was an ironclad, shallow draught vessel equipped with two guns in a revolving turret, built in New York in 1862 after a design by John Ericsson. She fought the famous battle against the Confederate ironclad Mer- rimack in Hampton Roads in March 1862. This was the first battle between two "ironclads." The Monitor lent its name to a whole class of naval vessels, the monitors (Kemp 1979). The Monitor acquired a great symbolic value for the North states in the Civil War and after the war for the United States of America. It sank off Cape Hatteras in December 1862 and was relocated with the help of modern underwater technique in 1973. In 1975 the site and the wreck of the Monitor was designated the first marine sanctuary of the U.S.A. In the 1970s and the 1980s underwater documentation was conducted on the site and also limited salvaging of artefacts from it, with the objective to arrange a Monitor museum. One of the objectives of this work has been to explore the possibilities to salvage the ship from the depths and preserve the Monitor on land (Miller 1978).

\section{England}

The Cutty Sark is the only remaining example of the British tea clippers. She was launched at Dumbarton in 1869 and the following year took part in the annual tea race from China to London. Later she began regular voyages in the wool trade from Australia and made some remarkably fast crossings. In 1936 she was presented to the Thames Nautical Training College and was towed to Greenwich for use as a boy's training ship. From 1954 she was put up at a dock at Greenwich and opened to the public (Kemp 1979).

\section{Finland}

The bark Sigyn was launched in Gothenburg, Sweden in 1887 . She was later sold to $\AA$ bo, Finland. The bark up to the First World War, sailed regularly on far-reaching trade expeditions to North-, Central- and South America and also to the Far East. Having been turned into a three-masted schooner she was sold in 1927 to the Aland Islands. She was laid up there in 1937 and was bought in 1939 by the newly founded Maritime Museum at the Åbo Academy, Finland and re- 
stored for exhibition. The aim was and is to save this ship as one of the few remaining sailing ships of the period (Grönstrand 1980).

\section{The Aland Islands}

The four-masted, steel-built bark Pommern was launched in 1903 in Glasgow. She was owned by the Aland shipowner Gustaf Erikson 1922-1953 and took part in the famous "grain-races," shipping grain from Australia to Europe in the end of the 1920s and the 1930s. When she was taken out of use, she was donated by the owner to be preserved in the harbour of Mariehamn as one of the few sailing merchant ships still existing in an original state (Greenhill \& Hackman 1986).

\section{England}

Queen Mary R.M.S. was the Cunard Company's transatlantic liner which, along with the Queen Elisabeth, may be said to have constituted the ultimate in size, speed, and luxury of such vessels before the volume of ship-borne transatlantic passenger traffic dwindled in the face of the competition from air travel. The Queen Mary was launched in 1934. After prewar transatlantic traffic she and the Queen Elisabeth were used extensively during the war for troop-carrying. Queen Mary reverted to her passenger-liner role after the war. She was finally withdrawn and sold in 1967 to an American company which has berthed her at Long Beach, California as a tourist museum and hotel (Kemp 1979).

\section{Norway}

The Fram, used by the Norwegian polar explorers Nansen and Amundsen for explorations in the Arctic and Antarctic around the turn of the century, is exhibited in a special museum in Bygdöy just beside the Norwegian National Maritime Museum and the Kon-Tiki Museum (see below) (Svensk Uppslagsbok 1937).

\section{Russia, former Soviet Union}

The cruiser Aurora, built in the year 1900 for the navy of the Russian tsar regime, took an active part in the communist revolution in October 1917. It was then preserved as a memorial of this event, moored on the river Neva in Leningrad, present-day St Petersburg (Brouwer 1985).

\section{USA}

The Jeremiah O'Brien is the last unchanged Liberty ship, built together with 2750 others during the Second World War especially for war transports. The ships were built with low costs and on a conveyor principle. The Jeremiah O'Brien, together with several of its sister ships, took part i. a. in the shipping of materials to France from England after the invasion in Normandy in 1944. It was taken out of service in 1946, and since 1980 it is restored, berthed, and on display in San Fransisco, commemorating the tasks of the Liberty ships during the war.

\section{Norway}

The Kon-Tiki raft, named after a Polynesian chieftain/god, the son of the sun, was built in the 1940s and used by the Norwegian explorer and anthropologist/archaeologist Thor Heyerdahl in his famous voyage over the Pacific in 1947. The raft is today on display in a special Kon-Tiki Museum at Bygdöy, outside Oslo, Norway, just beside the Norwegian National Maritime Museum and the Fram Museum (Heyerdahl 1948; Kemp 1979).

\section{England}

The Gipsy Moth IV is the $53 \mathrm{ft}$ ketch in which Sir Francis Chichester sailed around the world in an astonishing overall time of 274 days in 1966. Sailing his ship up the Thames to Greenwich after his return, Francis Chichester was knighted by Queen Elisabeth II who used the same sword with which Elisabeth I had knighted Sir Francis Drake aboard his ship Golden Hind at Deptford in 1581 . Gipsy Moth IV is preserved at Greenwich close to the clipper ship Cutty Sark (Kemp 1979). 


\section{A FEW CONCLUSIONS CONCERNING} THE SYMBOLISM OF OLD SHIPS

The above list of old ships on display around the world does not aim at a complete enumeration of such vessels. There are just a few examples to show how common ship symbolism is in Western society and how it can take different forms.

The descriptions of the symbolic expressions could be enlarged extensively to include, for example, symbols on the ships and concepts connected with these symbols. It would also be easy to show that such concepts have existed for a long time. As examples of the former one can mention the figureheads of ships, as a symbol of the ship's anima. Figureheads are also found on ships depicted in Scandinavian stone carvings from the Bronze Age, about 3000 years old, showing that this symbol has been in use for a long period of time.

The naming of ships very often is an expression of symbolism, something which is easily discernible if one reads through the list of examples of old, preserved ships above. For example, the naming of the royal or state warships is clearly connected to the power to which they belonged. The names of the ships are either taken from royal family members as in the case of the Mary Rose, named after the favourite sister of Henry VIII, and the Vasa, named after the Swedish royal family of the time; or from concepts of importance to the prevalence of power, as in the case of the Victory and the Constitution. Also in this aspect one can follow the custom of symbolism far back in time.

Preserved, old ships of the world today are often displayed in the centre of the society to which they belong, not seldom in places of national importance. They have a financial importance as they are numerous and attract the interest of millions of people every year, for example, as visitors to the museums - the "shrines" - at which the ships are preserved. The cultural and symbolic expressions around old preserved ships, as exemplified earlier in this text, in other words are ringing strongly and clearly in our own time and society.

It is quite evident from what has been put forward here that ship symbolism constitutes a manifold cultural complex in our society, with trails going far down into earlier time strata and social settings. In the list of examples presented here one can discern at least four symbolic evaluation structures or systems connected with ships.

There is the royal burial ship, in the examples given here of high age and excavated from tombs in which the ships have been put in connection with the burial of a royal person or a chieftain. Examples given are the Cheops boat in Egypt and the Oseberg and Gokstad Viking ships in Norway. In the two cases the ships are today on exhibit either in the near vicinity of the original royal tomb, in this case the Cheops pyramid, or near present day royal property, as at Bygdöy, Oslo.

There is the royal or state warship, like the replica of the Hellenic Trireme, the Mary Rose, the Vasa, the Victory, the Amphion, the USS Constitution, the frigate Jylland, the Monitor, and the cruiser Aurora. It can also be a ship with a close connection with a royal person, such as the ships of the emperor Caligula in Lake Nemi. Few royal or state warships in this list have been preserved from antiquity. Examples of such ships could be the two Viking war ships from about $1060 \mathrm{AD}$ in the Viking Ship Hall in Roskilde, if one interprets these as state warships in their original capacity as part of Viking Age fleets. Recently a replica was built of another prehistoric state ship, namely of a Hellenic Trireme. All ships in this category mentioned here, preserved in original, belong to the postmedieval period. They represent, in fact, all the centuries from the 16 th to the 20 th.

Several of these ships are preserved today in the ports in which they originally belonged, such as the Trireme, the frigate Jylland, and the cruiser Aurora. They might also be located at bases of royal navies to which the ships belonged or still belong, like the Mary Rose, 
the Vasa, the Victory and the USS Constitution. Some are preserved still afloat at their moorings, some in old naval dry docks and some in museums. These ships very clearly are presented as representives of the strength and vigour of the nation which built and launched them. They symbolize national endeavour in certain critical periods, often war situations, in which power was at stake or displayed - periods which are seen as historically important for the nation. In one case such a ship, namely the Monitor, is still resting on its wreck site at a depth of more than $70 \mathrm{~m}$ in the Atlantic, although plans to salvage it have been put forward. In this case the site and the remains of the ship, stressing the symbolic and historic importance of it, have been designated the first marine sanctuary of the USA.

There are also the ships of discovery or exploration such as the replicas of Columbus's ships, of the Mayflower and the Fram, the Kon-Tiki raft and the Gipsy Moth VII. In several cases ship replicas of this category have been used to repeat historically famous discovery expeditions, for example, when the replicas of Columbus's ships and the Mayflower were sailed over the Atlantic, commemorating the original journeys.

There is no special time limit for the examples given here of ships of discovery. The Kon-Tiki voyage, performed in the 1940s, was intended to throw light on and interpret an exploration process in prehistory. The Gipsy Moth voyage, on the other hand, happened just a few decades ago. A part of the symbolism of these vessels was and is homage to daring sportmanship, as in the case of Sir Chichester's circumnavigation of the globe in Gipsy Moth VII, or the daring enterprise of the Kon-Tiki expedition.

Refering to Viking ship symbolism, one can sometimes see a combination of the symbolism of the Viking ship as a royal burial ship with an evalutation of it as a ship of discovery. One example is the famous crossing of the Atlantic with the replica, named Viking, of the burial ship from Gokstad in 1893 , commemorating the early Viking travels to Vinland (Christensen 1986). Several other replicas of Viking ships have been built and sailed in Norway and Denmark during our century (see for example Crumlin-Pedersen \& Hartvig Nielsen 1965). One may see these as an expression of the strong identification in these societies with the Viking Age and the Viking ship and what this expresses in our time.

As a sideline in this context one may also note a high evaluation of the explorer, as a symbolic phenomenon. This is not least evident in Norwegian and Icelandic culture where it can be traced back to the tales of the Viking travellers a millenium ago; the views of Vikings as daring sailors and warriors, spreading the Nordic culture over the world a long time ago, can be parallelled with the evaluations around Scandinavian explorers of about a hundred years ago, with Norwegians like Amundsen and Nansen, and Swedes like Nordenskiöld and André. The same concepts seem to adhere to explorers such as Thor Heyerdahl in the last half of our century; and the Norwegian Ragnar Thorseth, who recently built and sailed the Saga Siglar, a replica of the Viking Age trading ship Skuldelev I, around the world in the 1980s (see below). This in turn again shows the Viking ship as an explorer's ship in a daring enterprise.

Finally, there is a fourth category of ship symbolism in the examples given, namely the category of the famous trading ship. Among the examples given here, from prehistory up to our time, there are ships which are said to represent peaks in the evolution of seafaring and trade, as in the case of the Viking trading ships at the Viking Ship Hall in Roskilde, representing the Viking trade system; the cog of Bremen representing the trade system of the Hanseatic League of the medieval period; the Batavia representing the Dutch East India trade and its importance for European economy in the 17th and 18th centuries; the Great Britain representing the beginning of the building of ships of iron and seafaring 
under steam in the 19th century; and the Cutty Sark, the Sigyn, the Pommern, the Queen Mary and the Jeremiah O'Brien, all representing different phases in seafaring, in trade and also passenger traffic, in the 19 th and 20 th centuries.

Inherent to an understanding of the symbolism of the ships in this category is an occasional element of daring trade competition, as in the case of the big sailing ships in the tea or grain trade and the competition races staged between these in the late 19th and the early 20th century. It can also be courageous war roles played by cargo or passenger ships, for example, the war transport role of the Liberty ship Jeremiah O'Brien, or the troop transport role of the Queen Mary during the Second World War, which motivate the exposition of them as historic ships or ship symbols.

One may see ships of discovery like the Columbus ships or the Mayflower, the original ships having been trading ships, as further expressions of trading-ship symbolism, both being symbols of the colonisation of the Americas, a development which had a very big effect on world trade and economy. The way in which the preserved ships of trade are described emphazises the economic power and importance of the development or period of seafaring they represent.

An evaluation which recurs in connection with all of the four categories of old preserved ships described here is that the ships exhibited are all said to represent a peak in shipbuilding technique in their time.

In the following text I will concentrate on just one aspect of ship symbolism which has had a special role in Swedish society. I will deal with the projections during the last few hundred years of the royal warships or the regal ships.

THE ROLE OF THE ROYAL WARSHIP IN THE DEVELOPMENT OF MARITIME MUSEUMS

While the big sailing warships vanished from the navy and as features of our environment in the late 19th century, the interest in them lived on. There developed an interest to preserve the memory of them in different forms. Naval officers created, for example, historical collections of the navy, commemorating the history of the Swedish Navy and its glorious moments. These were based on the collections of old ship models of the navy, models once built for designers' or other professionals' aims. These model chambers were in existence already in the 18 th century at the naval bases in Stockholm and Karlskrona. The early naval collections are the origin, or an important part of the origin, of the Swedish National Maritime Museums in Stockholm and the Navy Museum in Karlskrona, the only large museums in Sweden which commemorate the navy (see for example Nordlinder 1988).

\section{EARLY DIVING OPERATIONS AND} SALVAGE WORK ON THE WRECKS OF ROYAL WARSHIPS FROM "THE GREAT ERA" OF SWEDISH HISTORY

This interest in the big sailing warships appears in other shapes as well. The development of the diving technique with the heavy diving suit started within the navies of the world in the first half of the 19th century (Sundlöf 1978:18). In close connection with the start of the use of the heavy diving suit, there developed in Sweden a strong interest to dive down to and salvage from the wrecks of old sailing warships of the 17 th and 18 th centuries, foundered in battle or otherwise. The first known evidence of such divings are those performed on the initiative of the lieutenant in the mechanical corps of the navy, Anton Ludvig Fahnehjelm, in the 1840s. In an application in 1844 he asked permission to perform salvage operations for two years on a naval ship in Stockholm harbour which sank more than 200 years ago. He also includes evidence in his application that this ship was the Vasa, salvaged 120 years later (Hafström 1961:451). A map recently found in the archives of Stockholm City Museum 
gives evidence of an early interest in the wreck site of the Vasa. It may perhaps be connected with the application of Lieutenant Fahnehjelm. On this map one can see a depiction from the 19th century of the part of Stockholm harbour in which the Vasa was lying, with a marking of the location of the wreck of this ship.

It is not known whether Fahnehjelm ever organized or performed divings or salvaging on the wreck of the Vasa. At present we do not have access to any historical sources giving evidence of this. On the other hand, it is known that during 1842 he salvaged a large amount of effects from sunken ships, partly from the bottom of the sea and partly from the bottom of Stockholm harbour, at a depth of several fathoms (Hafström 1961: 466). It is quite probable that one of the wrecks in Stockholm harbour on which he organized divings and salvagings was the Vasa.

Another early example of salvaging from an old warship on the sea bottom is also connected with the diving activities of Fahnehjelm. In 1844 he was responsible for diving operations on the wreck of the Swedish warship Nyckeln, lost in battle in 1679 in Kalmar Sound, in order to take up parts of the ship's inventory (Hafström 1961:465).

Although this subject is far from thoroughly studied one can glimpse the existence, during the span of the latter part of the 19th century, of a series of diving operations on the wrecks of old warships from the 17 th and 18 th centuries in Swedish waters. These operations were usually combined with the salvaging of objects from the ships and were managed by different parties of which groups of navy divers seem to have been the most active. The salvage operations during this period, known so far on the wrecks of old royal warships, are:

- the salvaging in the 1840 s on several wrecks in Stockholm harbour, the Stockholm archipelago, and Kalmar Sound in connec- tion with A. L Fahnehjelm's diving experiments. One wreck known to have been subject to his divings was the Nyckeln, which foundered in Kalmar Sound in 1679. It is possible that diving activities were also performed on the Vasa (I) in Stockholm harbour (Hafström 1961:451).

- the salvaging in 1867 and possibly also later of parts of the hull of the Nya Riga, which foundered in the harbour of Karlskrona in 1719; the operations were performed by navy personel and divers.

the salvaging in 1868 of three iron guns, an anchor, and about 1000 cubic feet of ship timbers (black oak) for the manufacture of furniture, etc. from the Riksäpplet. The ship foundered at Dalarö in 1676. Also parts of the hull were taken up after blasting it to free the ship's timbers. The operations during 1868 are said to have taken more than one year's time and were organized by the manager of the Stockholm Diving Company (Stockholms Dykeribolag), C. Santesson (Dagens Nyheter 3/9 1921). According to newspaper information at the time, it seems that other parties were also active on the wreck earlier in the $1860 \mathrm{~s}$, for example, two students at the Technical High School in Stockholm. This has not yet been subject to investigation (SMA).

- the uncovering of and salvaging on unidentified wrecks of warships in Ystad harbour in 1868-1869, performed by construction workers dredging in the harbour, under archaeological supervision.

- the uncovering and recording in 1874 of the unidentified wreck of a warship at the site in the ground of the old naval base on Blasieholmen in Stockholm

- the salvaging of guns in 1876 from the unidentified wreck of a warship in Ystad harbour.

- the salvaging in 1880-1883 of iron guns and other artefacts, sold for scrap value, from wrecks of ships in a military transport, scuttled under war conditions in Strömstad harbour in 1719; the operations were performed 
by commercial salvagers.

- the salvaging in 1896 of parts of bronze guns and a large number of cannon balls from the wreck of "a ship of the line," supposedly the wreck of the Västervik, which burned and sank in 1676 outside the quay of the naval base in Stockholm.

Similar activities were also organized in the 20th century. Salvage operations on and other engagements in wrecks of royal warships of the 16th - 18th centuries which are known from this period are:

- the salvaging in 1905 of parts of the hull of the Hedvig Sofia, scuttled in the harbour of Karlskrona in 1730

the salvaging in 1908-1909 of many artefacts, including iron guns, from the Danish warship Enighed, sunk or scuttled in a war situation outside Kalmar in 1679

- the salvaging in 1908-1909 of many artefacts from the Swedish warship Nyckeln which was lost in the same year in the same area

- the search and survey of the site of the Riksäpplet by the diving company Stannum Ltd. in order to localize guns. None such were found (Dagens Nyheter 19/9 1921)

- the salvaging about 1920 of artefacts from the Samson, which foundered in Landskrona harbour in 1658

- the salvaging in 1920 of bronze guns from the site of the Riksnyckeln which foundered at Viksten in 1628

- the salvaging in 1921 of many artefacts from the Riksäpplet, which foundered at $\mathrm{Da}$ larö in 1676

- the salvaging in 1921 of many artefacts from the Gröne Jägaren, which foundered at Dalarö in 1676

- the plans to salvage the Vasa (I) or guns from it, in Stockholm harbour in 1921 (Stockholms Tidningen $22 / 8 ; 25 / 8 ; 4 / 91921$ ).

- the salvaging in 1923 of iron guns, handweapons etc from the Greve Mörner, which was part of a naval force under the command of the Swedish naval officer and privateer Lars Gatenhielm, and which sank in a nightly assault on Gothenburg harbour in 1719

- the excavation and salvaging in 1930 of an unidentified ship armed with wrought-iron guns, presumably built in the 1520 s. The ship had foundered at Riddarholmen in Stockholm harbour

- the excavation in 1932-1934 of the naval boijer Kråkan which foundered in the Kalmar harbour in 1650

- the salvaging in the 1930 s on the armed merchantman Constantia, enroled in the navy and sunk in battle in Blekinge skärgård in 1676

- the underwater archaeological excavation in 1933-1938 on the carvel Elefanten which foundered at Björkenäs in Kalmar Sound in 1564

- the salvaging in 1933 on the wreck of an unidentified warship which foundered in Marstrand harbour

- the uncovering and the salvaging in 1941 of parts of the hull of the Carolus Rex, scuttled in the navy shipyard in Karlskrona in 1724

the salvaging in 1953 and the following years, by the Swedish National Maritime Museum and the Navy, of iron guns and other artefacts from the Riksäpplet at Dalarö

the salvaging in 1953 and the following years, by the Swedish National Maritime Museum and the Navy, of iron guns and other artefacts from the Gröne Jägaren at Dalarö

- the salvaging on and the preparations for the raising in 1956-1961 of the Vasa (I), which foundered in Stockholm harbour in 1628

- the salvaging in 1958 , by private parties, of the rudder of the Riksnyckeln at Viksten

the salvaging from the end of the 1950 s to 1966 of the remains of the hull, as well as a big number of cannonballs and other objects, from the wreck of another ship with the name Vasa (II), which foundered in Djurhamn in 1623

- the salvaging in the 1960 s of parts of the 
hull of the wreck of the Neptunus, scuttled as a defence barrier in Oxdjupet Sound in Stockholm archipelago in 1659

- the salvaging in the $1960 \mathrm{~s}$ of parts of the hull of the wreck of the To Löver, scuttled as a defence barrier in Oxdjupet Sound in Stockholm archipelago in 1659. The ship was originally a Danish warship, taken as a prize by the Swedish Navy.

- the recording and the salvaging from the beginning of the 1960s of artefacts from the Svärdet which foundered in Landskrona harbour in connection with war activities in 1658 .

- the salvaging from the beginning of the 1960s of bronze guns and other artefacts, as well as recording on the Danish warship Sophia which foundered in the Gothenburg archipelago in 1645.

- the investigations and salvaging, starting in 1965 , of wrought iron guns and other artefacts from the wreck of a warship considered to be the Danish ship Engelen in the combined fleet of Denmark and Lybeck, which foundered outside Visby on Gotland in 1566.

- the investigations and salvaging, starting in 1965 , of wrought iron guns and other artefacts from the wreck of a warship considered to be the Josua from Lybeck in the combined fleet of Denmark and Lybeck, which foundered outside Visby on Gotland in 1566.

- the salvaging in the 1960 s of iron guns, ship timbers and other artefacts from the frigate Bellona which foundered near the town of Öregrund in 1809.

- the partial excavation and the salvaging of bronze guns and other artefacts from the Riksnyckeln at Viksten in the early 1970s.

- the partial excavation and the salvaging of wooden sculptures and other artefacts from the Riksäpplet at Dalarö in the 1970s, 1980s and 1990s.

- recording in the first half of the 1970s on the wreck of the Swedish frigate Birger Jarl which sank outside the coast of Själland, Denmark in 1813.

- the salvage operations and the recovery of artefacts from the armed merchantman Con- stantia in the Blekinge archipelago in the 1970s.

- the salvaging of ship's timbers from the wreck of the Gröne Jägaren, lost at Dalarö in 1676; the activities were conducted in 1977 by the navy.

- the excavation and the salvaging from 1980 onwards of many bronze guns from the Kronan which foundered in battle east of the island of Öland in 1676.

- the recordings in 1991 on a warship wreck in Nämdöfjärd Bay, at that time assumed to be the remains of the Lybska Svan of the Swedish Navy, which foundered in 1524.

An overview of the salvage and investigation enterprises presented here was originally given in Cederlund 1983. It has since been supplemented with new information. If no other source is given, the information is taken from Cederlund 1983 or the Marine Archaeological Archives (SMA) at the Swedish National Maritime Museum.

THE SALVAGE AND INVESTIGATION OPERATIONS ON WRECKS OF ROYAL WARSHIPS IN A HISTORICAL PERSPECTIVE

A few characteristics are easily seen if one looks at the activities described in the former sections in a historical perspective. Of importance is the extent to which the interest in the remains of old warships has been demonstrated in the Swedish society for several generations. Few of the operations enumerated here have been of small scale, regardless of motives behind them. In many cases it has been a question of underwater work extending over several years and demanding quite imposing salvage and diving equipment and other material resources. The projects have also often awakened a widespread interest among the general public, as well as among groups and individuals high up in the social pyramid of society, something which will be exemplified later in the text.

Looking back today on the earlier projects, 
in the "turned around looking glass of time," the former look less imposing than many projects of the same type which occur today or in our own lifetime. Of the extensive salvage or excavation operations on wrecks of old warships contucted and attracting high interest a few generations ago, there may remain today just a heap of forgotten timbers in the storehouse of a museum, some articles in daily papers of the time, or summary reports of the activities. The lack of antiquarian reports from the early operations has left us with little information about them.

Due to richer historical sources and improved reporting, the events of the 20 th century are better known than the earlier events. As time passed the antiquarian engagement and interest in these events grew. This interest seems to have existed already from the beginning, but it grew successively in importance. In other words, the cultural interests and the ones of the museums came to play an increasingly important role throwing the commercial aspects and the interests of private collectors in connection with the salvage operations on old warship wrecks into the shade.

\section{THE ROLES OF THE NAVY AND THE NAVAL OFFICERS}

The activities on the wrecks of old men-of-war have been performed to a great extent by naval officers or persons with a close connection with the Swedish navy. This group has organized most of the underwater operations on the wrecks of old warships, a series of events going on since the 1840 s and into our own time - that is, for about 150 years.

The first case of this seems to be Fahnehjelm's operations in the Stockholm harbour and archipelago and in Kalmar Sound in the years before 1850 , mentioned above. Fahnehjelm was attached to the mechanical corps of the navy. The extensive salvaging on the Nya Riga in the 1860s was performed by navy personel and divers in their service and as training. The same interest clearly can be seen in our century as well. The extensive salvage operations on the Enighed and the Nyckeln in the years before 1910 were headed by a regimental veterinarian - Alfred Bäckman - from Karlskrona, where the main Swedish naval base is situated. The operations were followed and supported by the naval officer Jakob Hägg, who at that time had the responsibility for the historical collections of the navy in Stockholm. When the salvage operations on the Riksäpplet and the Gröne Jägaren were staged ten years later, one of the controllers of the antiquarian aspects, appointed by the Central Board of National Antiquities, was a commander in the navy, Mr Lennart Stackell. The navy and its commanders took great interest in the activities and they also took care of the finds retrieved (Dagens Nyheter and Svenska Dagbladet September October 1921). When the excavation of the Elefanten started ten years later, in the early 1930s, it was organized and led by a commodore in the Navy Supply Corps, Mr Carl Ekman. Ten years later, in 1941, the hull of the Carolus Rex was uncovered at the navy shipyard in Karlskrona, and sections of it were removed for conservation and exhibition at the Navy Museum there and at the National Maritime Museum in Stockholm. This was monitored by a naval engineer then commissioned in Karlskrona, Mr Gustaf Halldin, a man with a great interest in the history of the navy. When in the early 1950s, ten years later, the National Maritime $\mathrm{Mu}$ seum and the navy cooperated in the planning and performance of salvaging work on the Riksäpplet and the Gröne Jägaren, the enterprise was led by a retired commander of the navy who was curator of the naval collections at the museum, Count Edward Hamilton. At that time cooperation had been established between the museum and $\mathrm{Mr}$ Anders Franzén, who a few years later located the Vasa (I) in the harbour of Stockholm and revived the interest in this wreck.

Several of the persons engaged in the Vasa project, its planning and execution, were naval officers. This was, for example, the case with 
the manager of the salvage operation, Commodore Edward Clason; commander Bo Cassel was also engaged in the preparations for the salvaging, as were as the two press officers, the commanders Hans Blenner and Bengt Ohrelius.

Many times units of navy divers have used wrecks of old warships as locations for diving exercise. One argument has been that they consider them to be "their own." In the 1960 s the Naval Technical and Economical Board still formally retained state-granted ownership of its own old naval ships, even if these were two or three hundred years old and long since wrecked. For instance, when the recovery of the wreck of the Vasa (II) in Djurhamn was proposed in 1964, the Board formally claimed ownership of it and on the basis of this position presented the wreck to the Central Board of National Antiquities for investigation.

The navy has supplied both base ships and material for use in a number of underwater salvagings and investigations on old warship wrecks, for example, on the Nya Riga in the 1860 s, the Riksäpplet in the beginning of the 1950s, and to a high degree on the Vasa (I) in Stockholm harbour a few years later as well as on the wreck of the Kronan today.

(As references to this section see Cederlund 1983, SMA, and literature on the salvaging of the Vasa and the Kronan.)

\section{THE ROLES OF THE NAVAL TECHNICIANS}

In June 1817 the lieutenant in the construction corps of the Swedish navy, Mr Carl Daniel Pettersson, donated "a piece of wood from the keel of the Swedish man-of-war, the ship Götha", to the Academy of Lund, "in the case this memory should be found worthy of a place in the historical collections of our nearest academy." The reason for this, according to a letter by Pettersson following the donation, was that the ship, of 76 guns, was the first warship to be built at the naval base in Karlskrona after the founding of the same in the year 1680. According to the donator, it had also taken part in the battle against the Danes at Möen in 1710. In the beginning of the 19th century the remains of the vessel, according to Pettersson's letter, were lying at a shore near the civil shipyard (Sw. "kofferdivarvet") in Karlskrona (where he worked at that time as a master shipwright) (Lunds Historiska Museums Arkiv; Hillbom 1975:2).

This is the first case I know in which an act of reverence, including the rescue of an original part of an old Swedish warship, was performed in order to commemorate important events in the history of the navy. A shipbuilder and lieutenant in the construction corps of the navy is the agent in this case.

The fact that Lieutenant C. A. Pettersson, who paid homage to the memory of the old warships by saving parts of one of them, belonged to the Construction Corps of the navy does not seem to be a coincidence. The profession of a naval officer is as such highly technical. Several of the naval officers who later were engaged in the salvaging of objects from old warships were officers with a technical attribution in the navy. One of the first, A. L. Fahnehjelm, who was interested in and did diving on wrecks of old warships in the 1840 s, as described above, had a professional technical occupation within the navy and also a great general engagement in the subject in his capacity as a technical inventor.

There are many close connections between this group of navy professionals and several sectors of the civil, technical world. There is also a clear, long-time interest shown by civil technicians in the matters of the wrecks of regal ships. As an early example, an anchor was salvaged from the Riksäpplet in the 1860s. It was done by two students from the Technical High School in Stockholm (SMA).

Anders Franzén played an important role in generating the plans to salvage the Vasa in the 1950s. Mr Franzén, originally a student at the Technical Highschool in Stockholm, was later, from around 1960, for a long time employed in a technical occupation at the 
Naval Technical and Economical Board. At the end of his career he was given a special position by the government at the Technical High School in Stockholm - as a researcher within the department of shipbuilding.

Many were and are the naval and civil technicians who have involved themselves in the Vasa project voluntarily because of pure interest in its many technical and practical aspects.

Starting with the letter of Carl Daniel Pettersson from 1817 , it is possible to trace a continous tradition of interest, within the group of naval technicians mentioned here, in the material remains of old naval ships already from the second decade of the 19th century up to the present century; it is also possible to identify two early bearers of the same tradition within the group of technicians knowledgeable in and occupied with shipbuilding within the navy several generations ago.

Carl Daniel Pettersson, born in 1787, was the son of a master shipwright in Karlskrona. He was accepted as an apprentice at the Constructions Corps of the navy in 1804. There he became one of the pupils of Fredrik Henrik af Chapman (1721-1808), then still active, and he was also trained by him (Hillbom 1975:2). Af Chapman is the ship designer who is considered the most outstanding naval designer and engineer in Sweden through his personal capacity and work effort. Unquestionably he had a great influence on the development of the big sailing warships of Sweden in the latter part of the 18th century. In his unusual capacity he has also been honoured as one of the greatest men in Swedish shipbuilding history. On the one hundred year anniversary of his death he was honoured with a memorial speech at a special memorial festivity in Gothenburg. The speaker, H. Lilliehöök, a high ranking naval engineer, introduced af Chapman with the following words, which give an impression of the terms in which af Chapman's person and deeds can be and have been described in this context: "...when we have gathered here to honour the 100-year memory of one of those unforgettable men, who by the force of their genius, morale and courage, in combination with untiring work for the public weal, to such an extent has earned the thankfulness of the country..."

(Lilliehöök 1909: 3).

Carl Daniel Pettersson became an educated master shipwright and worked as such at the civil shipyard in Karlskrona. He was appointed lieutenant in the Constructions Corps of the navy in 1815 . He became a well known and highly appreciated builder of especially civil merchantmen but also of ships for the navy (Hillbom 1975: 3 and 6). In 1842 the first Shipbuilding Insitute in Sweden, for the education and training of master shipwrights, was established at the civil shipyard in Karlskrona, then owned by Pettersson. After his retirement in 1846 he interested himself solely in his big hobby, the study of ancient times ( $\mathrm{Sw}$. fornforskning). It must have been this interest which a few decades earlier encouraged him to save and donate a piece of the keel of the naval ship Götha to the Academy in Lund.

One of the first pupils at the institute was Carl August Lindvall (1829-1918) who was accepted to pursue the training there in 1843 . He became a master shipwright in 1848 and was later employed as head of the mechanical works at Motala Verkstad (Motala Mechanical Workshop). Still later, after studies in England and Scotland, he was appointed head of the mechanical works at Bergsund Shipyard in Stockholm. Both of these shipyards were among the biggest modern shipyards in Sweden at the time. He became the manager of the Bergsund Shipyard in 1875 (Hillbom 1975:11).

In 1874 one can record his interest in the material remains of old sailing warships. He is namely the man who documents the remains of a hull of a big man-of-war excavated that year in connection with work at the former site of Stockholm's Skeppsgård, the main 
naval base in Sweden between the 1560s and the 1640s, located at Blasieholmen in the center of Stockholm. A description and documentation with plans of the ship remains was also published by him the same year (Cederlund 1983:212-213).

In a small article in Teknisk Tidskrift 1908 Lindvall gives a few views on F. H. af Chapman. What he writes is really a few personal memories or hearsays about the great man. He tells that these had been told to him by an old man who had himself been a pupil of af Chapman's, namely, the master shipwright Carl Daniel Pettersson. The latter had been assisted by the young Lindvall in 1845 in copying construction plans of ships, "and enjoyed talking about events in the old days."

We have here two men fostered in the same training system and traditions of the navy and its Construction Corps. Both had evidently an interest in the historical background of their metier. Both had been so interested in the history of the navy and the big sailing ships of the navy that they had taken the trouble to save or record the material remains of such (Lindvall 1908: 17).

\section{THE ANTIQUARIAN AND THE ARCHAEOLOGICAL APPROACH}

Already at an early stage one can see the appearance of an antiquarian or museological interest in the finds from wrecks of old naval ships in the depths. The first expression of this so far recognized maybe C. D. Pettersson's donation in 1817 to the collections of the Academy of Lund, even if the item then donated came from a wreck of an old naval ship lying at a shore. The same interest was also evident when a big anchor was salvaged from the site of the Riksäpplet in the 1860s. It was towed on a raft to Stockholm harbour to be shown to an interested public there. A few years later the guns salvaged from the same wreck were taken to the Ethnographical Collections in Stockholm and later to the open air museum Skansen. When the salvaging on the Enighed and the Nyckeln in Kalmar
Sound was performed in the early 1900s this was done for commercial reasons. The artefacts recovered were offered to and bought by museums and also private collectors. A museum curator (and naval officer) - the curator of the historical navy collections in Stockholm - was advising the salvage crew on the identification of items retrieved. Also during the salvaging at the site of the Riksäpplet and the Gröne Jägaren in the early 1920s antiquarian interests were represented in the shape of the conservator of the Central Board of National Antiquities, Mr Erik Sörling and the commander of the navy, $\mathrm{Mr}$ Lennart Stackell. The excavation of the Elefanten in the 1930s developed, as mentioned above, into one of the first archaeological excavations under water in Sweden. The results, in the form of a reconstruction of the stern of the Elefanten, were exhibited at the National Maritime Museum for fifteen years, between 1938 and 1953 (Cederlund 1983:48).

It is, on the other hand, quite clear that the salvage operations on the wrecks of old menof-war in the 19th century, and also later, to a high degree were just salvage operations. What we today call marine archaeology appears late on the scene. Not until the excavation of the Vasa (I) in 1961, performed above water, can one speak of the staging of a professional, archaeological investigation on a wreck of a royal warship. A prominent forerunner in this respect was Carl Ekman. In his excavation of the Elefanten in the 1930s he used quite modern marine archaeological recording techniques, although the archaeological registration and the report on the investigation were never undertaken. The late appearance of archaeological standards in this context can be explained by the fact that general archaeology was developed in quite another part of society than the early underwater operations.

Decisive for an antiquarian and, later, a marine archaeological approach to the finds of old warship wrecks was also the establishing of a law in 1967 to protect the wrecks of old 
ships by an amendment to the law of Ancient Monuments, a protection which did not exist earlier. The amendment integrated old wrecks into the archaeological care of ancient monuments in general which had been established already one hundred years earlier for archaeological remains on land (Cederlund 1988). An interesting aspect on the evaluation of the wrecks of old warships is the fact that paragraph 15 in the Ancient Monuments Act, which places a unique monument under temporary protection pending investigation, is known to have been used only three times for the wrecks of old ships. These were the sites of the Vasa, the Kronan and the ship which, in 1991, was assumed to be the Lybska Svan (see the list above). It has, in other words, not been assigned to any other type of old ship remains than the famous warships from the great era in Swedish history. This gives an idea of society's evaluations of the wrecks of the big warships, as cultural and national manifestations (SMA).

\section{THE COMMERCIAL INTERESTS}

The salvage operations of the 19th and 20th centuries: One primary and important reason for salvage work on old warship wrecks was already in the first known cases the commercial gains from it. This seems to have been a motive also for naval officers engaged in this work in the 19th century. In several of the early projects one important aim was to salvage the bronze guns of the ships, as well as the ship's timbers of so called "black oak" from the hulls. The objective was to sell the guns to collectors of antique weapons, and the black oak to carpenters and furniture manufacturers.

The value of the bronze guns. The metal in the bronze guns represented a high value in the 17 th century, the time period in which they were used on warships. This was the important reason why they were often cleverly salvaged already then. The original metal value of the old bronze guns has been maintained since the 17 th century. To this has been added their antique market value in more recent times. Time and again in connection with the salvaging of guns from old warship wrecks - i. e. from the Riksnyckeln in 1920 , the Riksäpplet and the Gröne Jägaren in 1921, in connection with plans to salvage from the Vasa (I) in 1921 as well as when it was realized in 1961, and on the Kronan in the 1980s - the supposition that the bronze guns represented enormous sums of money recurs. In 1920 five bronze guns found on the site of the Riksnyckeln were sold to the Swedish state for a very big sum at the time. The salvaging on the Riksäpplet and the Gröne Jägaren in 1921 had as a main aim to find more such guns. The former ship is described in the daily paper Stockholms Tidningen as "the dreadnought" of the Great War Era of Swedish History in the 17th century, with not less than eighty guns. A journalist created a whole series of articles which to a high degree concentrate on the possibility to find guns on the wreck as salvage efforts were underway - the guns being of great value and "relics of culture and war history."

The manager of the salvaging on the Riksäpplet, Mr Olschanski, and also Commander Stackell, were interviewed on their plans to salvage the wreck of the Vasa (I) in Stockholm harbour in 1921. The question had been taken up with the harbour authorities several times for permission to do so, but the proposal had been rejected as it would hinder the traffic in the harbour. At that time the guns, assumed to be still on board the wreck of the Vasa, were supposed to have a scrap value of 100,000 kronor, according to an article in the Stockholms Tidningen (it was not known then that most of the guns on the Vasa, which had not yet been localized on the bottom, had been taken up already in the 17th century) (Stockholms Tidningen 22/8; 25/8; 4/9 1921).

When the Vasa was salvaged in 1961 the value of each of the bronze guns had increased considerably compared to the estimates of the $1920 \mathrm{~s}$. One story told many 
times during the 1960 s was the one about the American millionaire, who put a check of 1 million dollars on the barrel of one of Vasa's guns, then on tour in the U.S.A., saying "you give me the gun and this is yours". When the Kronan was located in 1980 with dozens of bronze guns on the site, one could read the following in a Stockholm newspaper about one of the guns which had been salvaged : "its value on the antique market is 1 million crowns...Kronan is turning out to be Sweden's greatest treasure find ever... if it were permitted to sell one of those cannons to the United States for around half a million crowns, it would pay for the entire research project..."

Also iron guns have been and are given a value on similar occasions although on a lesser scale. Iron guns taken up from the bottom of Strömstad harbour 110 years ago were sold as scrap; and the company salvaging on the Enighed and the Nyckeln 80 years ago conducted an energetic sales operation to sell the iron guns retrieved to museums and private collectors (SMA).

The value of "black oak". "Black oak" is ship timbers which have blackened through a chemical reaction while in the water. It has long since been seen as very beautiful and suitable as raw material for the manufacture of furniture, wooden souvenirs, etc. When salvagers were working on the Riksäpplet in the 1860 s one goal was to get "black oak," since the hull was blasted to free ship timbers. Timbers taken up from the Nya Riga at the same time by navy divers were used to produce furniture, jewellery boxes, paperknives, etc. The salvage projects on the Enighed, Nyckeln, Riksäpplet and Gröne Jägaren around 1910 and 1920 all had the salvaging of "black oak" for sale as one of the objectives (Fig. 1). When the Vasa (II), sunk by fire at Djurhamn in 1623, was salvaged piece by piece in the first half of the 1960 s, it was done for the same purpose. The Stockholm market, thanks to this enterprise, was for a period of time flooded by souvenirs of "black oak"; cocktail bars in Stockholm suddenly had their interior decorated with 300 year old ship planks of the same material, etc (Cederlund 1983: 36).

Commercial involvement and gain in recent projects. In later times the commercial interest shown in connection with the salvaging of black oak from the old warship wrecks has been superseded by quite another commercial interest. This is well exemplified by the Vasa (I) project. Around 1960 the Vasa became a marketing asset for Swedish industry. Many donations were made in building material, services and money to help realize the salvage operations. In return the donators and others used the image of the Vasa in connection with public relations, advertising, etc. both in Sweden and abroad.

The wrecks of old, royal warships as tourist industry. One may see the commercial interest of the old warships and wrecks from yet another perspective. Beginning already in the 1860 s one can see a growing public interest in the warship wrecks and finds from them - evident in connection with the salvaging on the Riksäpplet on different occasions, on the Enighed and the Nyckeln, and on the Elefanten. The exhibitions of the Vasa (I) and the Kronan in later times have likewise attracted great public interest. The Vasa Museum is visited by about a million people each year, and the income generated from the admission fees is used to finance the museum. The Kronan project of today plays a similar role. The finds from the ship are housed in a new county museum, of importance to the tourist industry in the area.

The projects of today are very much motivated by and are an expression of a deliberate tourist policy. The high interest in the remains of old royal warships generates tourist incomes not only from the visitor entrance fees to the museums but also from the money spent by the tourists on travels, eating, staying in hotels, and taking taxis to see the ships. 


\section{MEDIA INTEREST IN THE OLD WRECKS AND THEIR SYMBOLISM}

Ideologically eloquent views have been projected many times in Swedish media in connection with finds of the wrecks of old warships. It is interesting to see how similar these expressions are over time. In general one can say that the media, in the context of the wrecks of old warships, have projected for a long time, and to a very high degree, evaluations of royalty or the memory of great kings and their reign, especially those of the "great war era" of Sweden or the era of the royal Vasa family (corresponding to the period from the beginning of the early 16 th to the early 18 th century); the "glorious" wars the kings fought; the weapons, especially the guns, they fought with; treasures of different sorts found on board the wrecked war-ships; and the remains of the sailors of the royal warships as the remains of national heroes.

The media evaluations around the old warships and the wrecks of them are shown very clearly in our society by the press during the last seventy or eighty years. One may assume that popular writings in daily news papers on subjects like the ones treated here are responses to a general interest in a phenomenon in society. If this is true, one may see that these finds early on attracted a great general interest. There is also another, alternative interpretation, namely, that certain journalists or certain daily papers have an interest in highlighting the activities on the wrecks of old men-of-war in order to market ideological evaluations connected with the latter. One might be able to see both these trends in the media in the last 80 years. It is, for example, no surprise that a conservative daily paper in Stockholm, Svenska Dagbladet, has been the most active in the marketing of finds of old warships during the last decades, from the highlighting of the Kronan to the presentation of the so-called Lybska Svan.

The media interest is very evident in the case of the Vasa (I) and the Kronan projects, the symbolic values of which have been mass-projected. The same appeared in a very similar pattern in the case of the presentation of the wreck initially introduced as the Lybska Svan in 1991. It would be of interest to make a press historical analysis of the media coverage of these and similar earlier events in order to study the cultural and ideological aspects. Here there is room only for a few examples illustrating the main lines in this flow of evaluations.

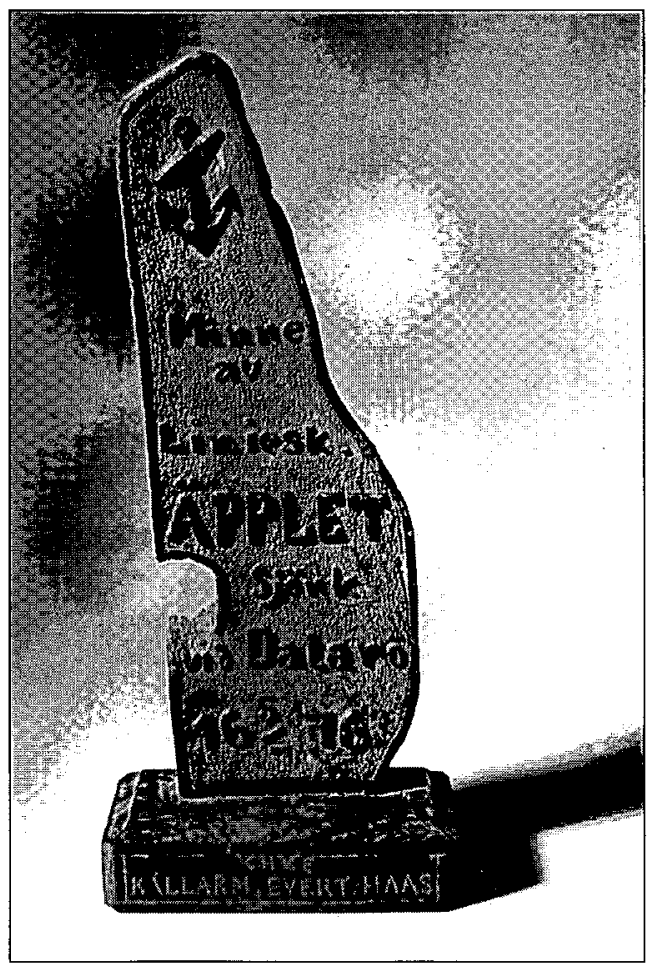

Fig. I. One of the many commemoration objects or "relics" manufactured of black oak, salvaged from the wrecks of regal ships sunk in Swedish waters.In this case it is a commemoration plate in the shape of an oak plank into which have been cut, underneath an anchor, the words: "Commemoration of the Ship of the Line Applet. Sank at Dalarö 5/7 1676". Underneath this is inscribed the name of the commander of the ship and his civil title (he was not a naval officer). The commemoration plate is not dated but was donated to the maritime museum collection in Stockholm in 1929.

Photo: The Swedish National Maritime Museum. 


\section{THE SYMBOLISM OF TREASURES}

Treasures of "the standard character," in the form of objects or coins of gold and silver, have been found in wrecks of old warships in Swedish waters, although it has not happened often. One example is the hoard of gold coins which was salvaged from the Kronan in 1982. It was presented in Dagens Nyheter on the 27th of October with the following words: "105 gold coins have already been found on board. One of them is a 6-ducat, of which only one other example has ever been found. On the collectors's market, this coin alone is supposed to be worth one million Sw. crowns." In the circumstances described here, treasures found in old wrecks do not seem to have the same importance as the ideological assets discussed. On the other hand, the treasure aspect has a connection with the former in different ways. One such is in the evaluation of the old guns salvaged. The economic and symbolic values, which these have been and are given, also give them roles as treasures in the way treasure hunters evaluate what they seek. Very good examples of this can be found in the articles written about the search for guns at the Riksäpplet and the Gröne Jägaren and the planning of this on the Vasa (I) in 1921. It comes back in very similar expression in articles about the find of the Kronan 60 year later. Examples of such expressions are given in the next section.

Another find category which has often been described as treasure is the "black oak" retrieved from the hulls of the wrecks, which is examplified further on in the text. The treasure aspect of black oak disappeared in connection with the salvage activities on the big warship wrecks in the earlier part of the 20 th century. On the other hand, it did appear in connection with the last big, commercial salvage project which took place as late as the $1960 \mathrm{~s}$. This was performed on the wreck of Vasa (II) at Djurhamn from the end of the 1950 s to 1966 - ending one year before the law amendment protecting these remains was introduced. An article in a weekly paper tells this treasure story (SMA): "Time for Vasa project number two - one which will give the initiator big money if all the signs don't fail... Piece by piece he aims to sell the glorious Vasa ship as souvenirs to American tourists... In a storeroom on the island of Essingen in Stockholm lies now black oak from Vasa with a value of several hundred thousand Sw. crowns...."

The concept of treasure can also be applied in this context to the meaning of "valuable relic." It is quite evident that one manufactured souvenirs of black oak from the old warships as "relics" of the latter. These "relics" seem to have been produced to commemorate the big warships of the great days. In several cases texts were engraved on the "relics," commemorating the ship and the salvaging of it. When black oak from the Nya Riga in 1867 was turned into furniture and souvenirs, an artist, for example, engraved the latter with the inscription:"1717 Riga -1867," commemorating the date when the ship foundered (a 150 year anniversary), the name of it, and the date of the salvaging of oak from it. When the many souvenirs of black oak from the Vasa (II), raised at Djurhamn in 1966, were manufactured a hundred years later, they were furnished with a small plaque of silver inscribed with a text explaining the origin of the souvenir and a commemoration of the old navy ship.

\section{THE SYMBOLISM OF THE SHIPS GUNS}

An early example of interest in the old warship wrecks, mirrored in the press, is a series of articles in the daily paper Barometern in Kalmar on the subject of the salvage operations on the Enighed and the Nyckeln about 85 years ago. The paper gives the readers many insights into the finds and the activities around them, evidently a response to a general interest. The author of the articles is among those engaged in the salvaging, the regimental veterinarian Alfred Bäckman. He writes in an enthusiastic way about the salvage 
operations, the finds made and the history behind them. His subjects of interest are easy to define. He advertises the black oak and its high quality and gives examples of what one can manufacture from it. Yet the finds which held his special interest were the guns and the ammunition for them, recovered from the depths. Bäckman uses many eloquent sentences on both thorough technical and historical descriptions of the weapons, as well as on attitudes of war romanticism which he connects with them.

What has been very evident and is a strong motivation for the salvage activity on the wrecks of old warships, is the interest in the old guns found on them. No other type of find has been so much in focus in the search for finds, in the imaginations and evaluations of the finders, and in the stories of the old ships told by the journalists. As can be seen in the list of operations on old warship wrecks given above, a great many of the projects have included finds of bronze or iron guns. Time and again for more than 100 years it has been the old ship's guns which have been recovered. Also in very recent projects the guns are in the centre of interest (Fig. 2 and 3).

There are several explanations for this. One is the commercial value of the cannon, treated earlier. Still, the commercial factor hardly explains completely the ongoing, vivid interest in old guns found in old warship wrecks. When reading newspaper articles on old warship wrecks written since the early century up till today, one can see the recurrence time after time of the descriptions of the guns as instruments of power and war. Guns were and are the "power tools" of society, which gives them also a symbolic strength.

In the archives of the Nordic Museum there are two photos from the open-air museum Skansen - one from 1898 and one from 1908 - showing the guns salvaged from the Riksäpplet in 1868. The latter have been arranged together with other old guns, side by side, to form a gun battery. They are guarded by men clad in soldier's uniforms from the beginning of the 18th century. On the back of one of the photos is written: "The camp of the soldiers of King Karl XII (in Swedish "Karl XII:s karoliner") at Skansen photographed in 1908." The reconstruction of a military camp from the time of king Karl XII, using the guns from the wreck of a warship in the fleet of the king's father - Karl XI - can definitely be connected to the nationalistic currents in the late 19th century in Sweden. This is the time of the epic novel "Karolinerna," published by Verner von Heidenstam in 18971898, which depicted Karl XII and his warriors as national heroes. (Fig. 4).

\section{THE HUMAN REMAINS OF NATIONAL HEROES}

Man has an expressed interest in the earthly remains of his forefathers. There are few objects that attract as much interest in an archaeological museum as the exhibit of a human skeleton from, for example, a prehistoric grave. This interest is also the case with skeletons from the wrecks of old warships. One of the themes which recurs time and again in conjunction with the wrecks of old warships is the interest in the earthly remains and the honouring of the seamen who paid with their lives when the ship went down.

The supporter of the salvaging on the Enighed in 1908-1909, Alfred Bäckman, gives in the newspaper Barometern vivid descriptions of the courageous roles of the heroes of the naval battles in Kalmar Sound (Bäckman 1908-1909). He wrote the following in Barometern in 1909 when, contemplating the ribs of a man that were taken from the wreck of this Danish warship: "It was doubtlessly one of the deck battery gunners who was torn asunder by the explosion of the ship or by an enemy shot...; it caused the aforementioned piece of his chest to land into the pile of cannonballs lying beside the gun, and now, after centuries of rest on the bottom of the sea, it has been returned to the light of day. How strange fate can manifest 
itself! Not even in the deepest darkest depths of the sea does one find peace. Nevertheless, this warrior from the 17 th century will sleep peacefully. He fell like a hero in a battle, so let us honour his memory, this unknown yet valiant enemy!"

When the Vasa was salvaged, the remains of the dead crew were accorded a great deal of interest. There has been great speculation about their identity and their fate. One popular writer in 1961 put it this way: "The position of the skeletons aboard the Vasa are evidence of how horrendous this catastrophe must have been on that day 333 years ago. Many of the dead men were discovered crushed up against the side of the ship. It is not difficult to imagine how runaway guns and other heavy objects could trap or crush the unfortunate seaman against the side...trapped on the gundeck, fighting amid rolling guns and inrushing water - trapped to die" (Widding 1961: 46).

During the course of the investigation of the warship Kronan this same interest recurred in an similar manner. One daily paper wrote, for example, on June 1, 1981: "We're swimming along beside the wreck. Sometimes a skull grins out at us with its empty eye sockets and white teeth in the brown cranium. Here and there lie long pieces of bone...it's been 305 years since anybody touched the guns. Maybe it's one of those who left his bones behind down here, maybe it's one of those who is now lying on his back, the empty sockets of his eyes staring straight up at the surface of the water and the sun above. The mind boggles... The Kronan had a crew of 842 men. Only 42 of them were saved, 800 drowned or were killed in the explosion. 240 bodies of these crew members floated ashore. The rest remain perhaps here in the wreck..." (Svenska Dagbladet 1/6 1981).

The people whose remains are found on the warship wrecks were Christians. They lived in a period of time and a culture which does not lie too far from our own. The human

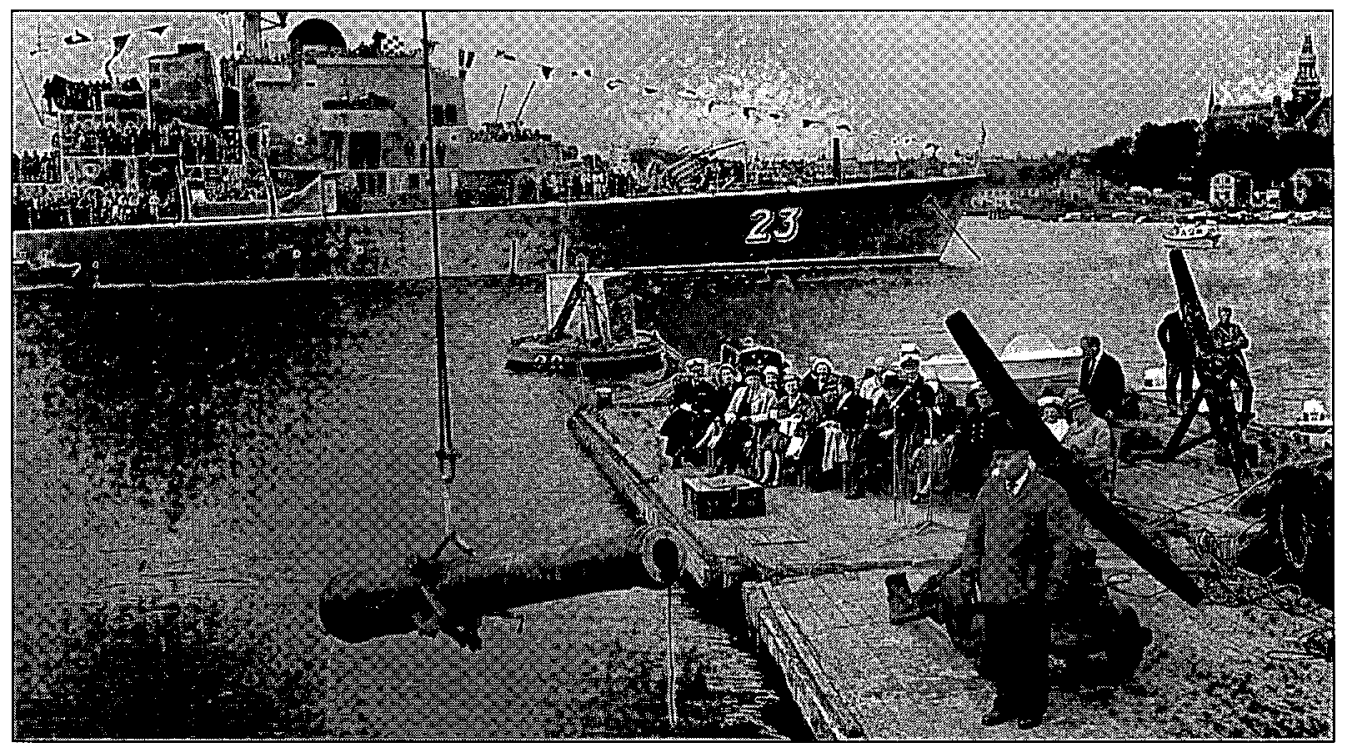

Fig. 2. In the media presentations of the preparations for and the salvage of the regal ship Vasa the raising of guns found onboard the ship was made a center of interest. The photo shows the raising of one of the bronze guns from the wreck still on the bottom, in connection with a congress of historians in Stockholm in August 1960. As a background to the event one of the ships of the Swedish navy of the time, a destroyer, has been anchored.

Photo: The Vasa Museum. 


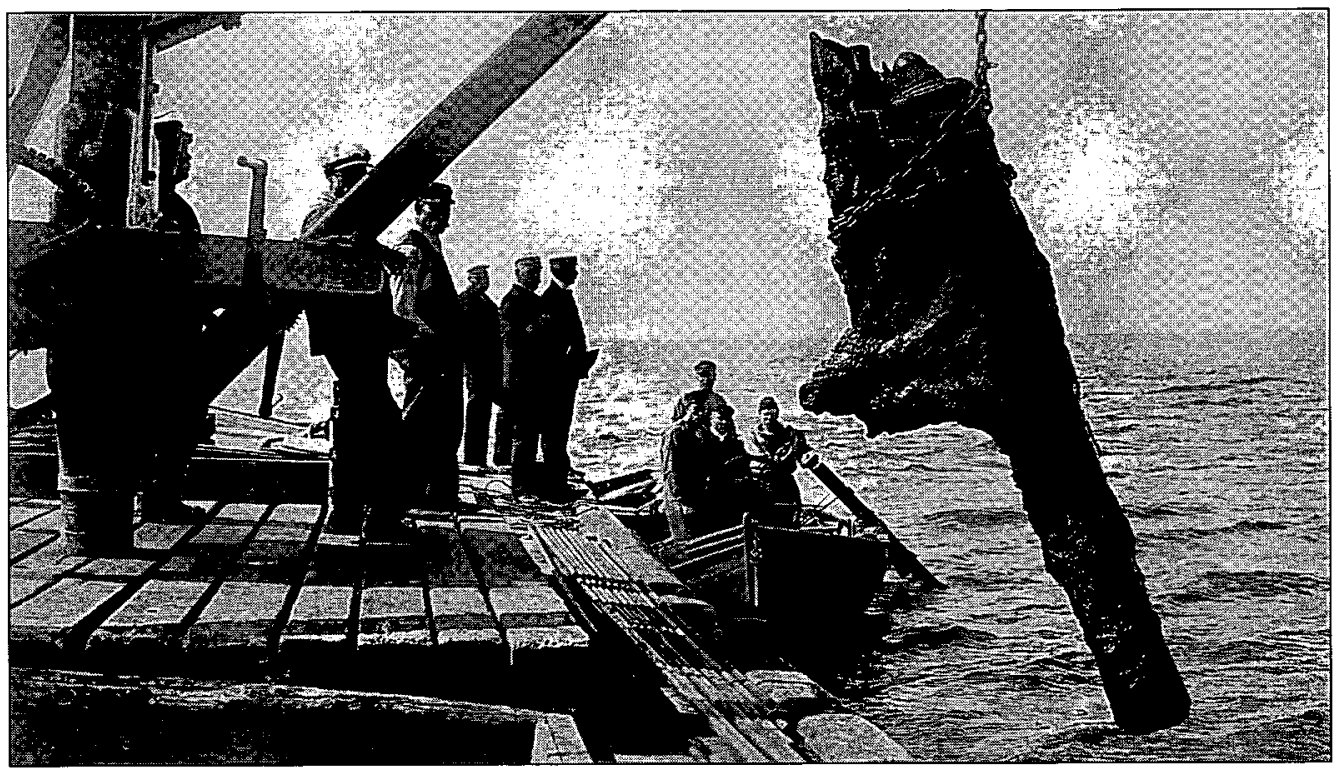

Fig. 3. The raising of one of the iron guns from the Danish warship Enighed, sunk outside Kalmar in 1679, in connection with a major salvage operation on this and another wreck in 1908 and 1909.

Photo: The Swedish National Maritime Museum.

skeletons of individuals that were found on board the Vasa were laid to rest in a special tomb in the cemetary of the naval base in Stockholm - the Galärvarvet - a few years after the salvaging of the ship. A honorary ceremony was held, led by the admirality incumbent, in the presence of, among others, three admirals. The hymn "Nearer God to you" was played by a military orchestra (Svenska Dagbladet 11/8 1963).

A short poem written by the Royal prince Wilhelm, a naval officer himself, was engraved on the gravestone:

Here is the resting place for those who after 333 years have been salvaged from the regal ship Wasa

Short was the cruise, long for those who sailed into eternity

They sacrificed their lives for their country At early aged deceased, late committed to rest in consecrated ground Wanderer, give the nameless a peaceful thought (translation by C. O. Cederlund)
The many corpses retrieved after the sinking of the Kronan in 1676 were at that time buried in the cemetery of the Hulterstad parish church on the island of Öland. The skeletons retrieved in connection with the investigation of the wreck of the Kronan in the 1980s have been buried in the same cemetery under honorary forms in our time.

\section{NAVAL WAR DRAMA AND PANEGYRIC}

There is a strong element of dramatic, nationalistic story-telling in the articles in the daily papers but also in popular books on the subject of the wrecks of old warships and the salvaging from and investigation of them.

Alfred Bäckman writes, for example, in the daily newspaper Barometern (Bäckman 1908-1909): "It is without doubt a strange impression you receive when you stand before these remains of what once was a massive, formidable ship of war. What memories are not indelibly linked with these objects now covered by shells! One's thoughts travel 


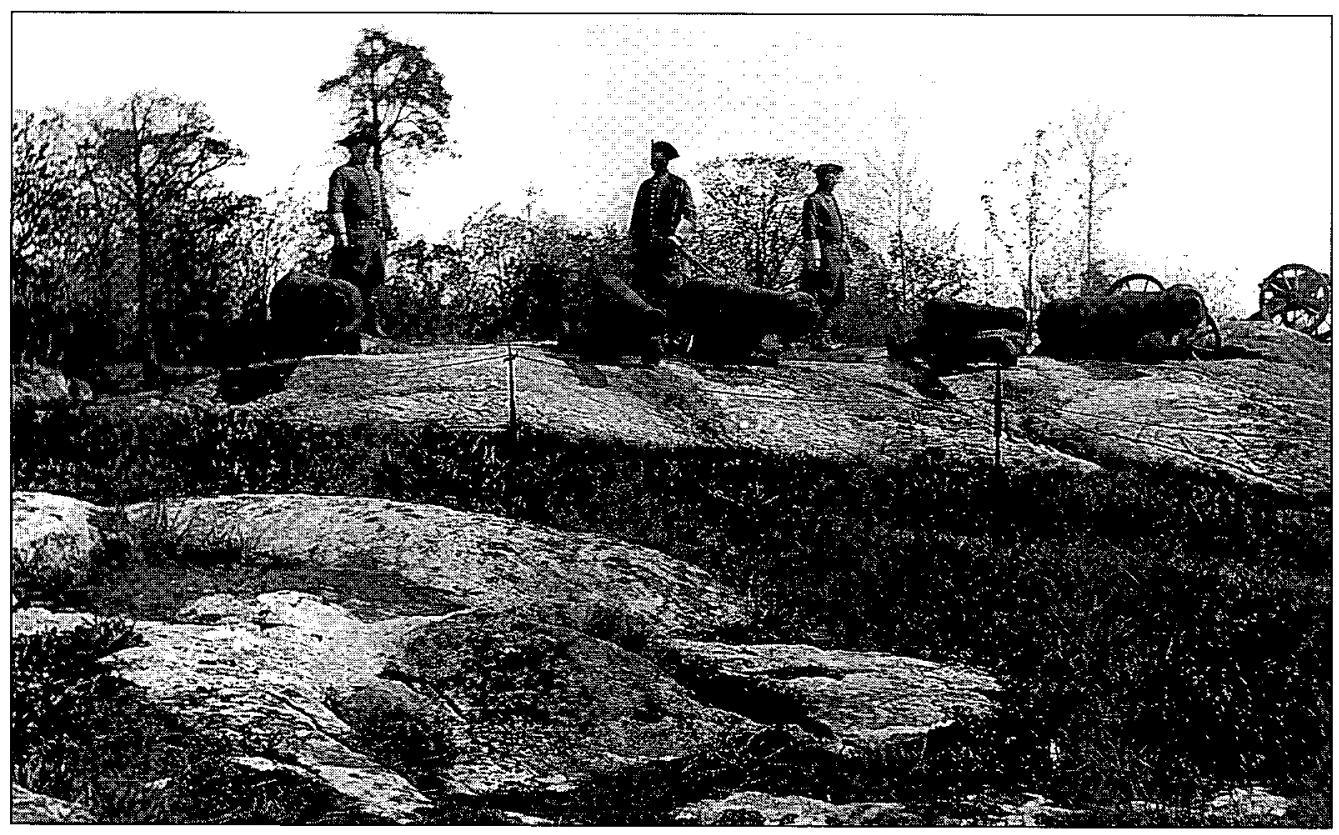

Fig. 4. "Karolinemas läger" - the camp of the soldiers of king Karl XII (1682-1718) - a reconstructed historical scene at the open air museum of Skansen in Stockholm in 1908. The three big iron guns on the scene were salvaged in 1868 from the wreck of the regal ship Riksäpplet, foundered at Dalaro in 1676 and one of the regal ships of Karl XI (1655-1697), father of the former king.

Photo: The Nordic Museum, Stockholm.

easily back to those who in battle were carried down to the deep and to the dreadful scenes these silent object once witnessed. What would they - if they could speak - be able to tell us about the last moments of the Enighed when the entire ship was one huge sea of fire before the flames finally reached the powder magazine and put an end to the horror and suffering."

When the Olschanski salvage company fished up black oak from the wreck of the Riksäpplet in 1921 those adventurous tones again were heard in a daily paper's descriptions: "By this week and maybe even on one of these very first days, the Olschanski company's salvage steamer Sigfrid, known to all since the summer of 1920 when during successful expeditions to Viksten (in Stockholm's southern archipelago) she saved a proud Riksnyckeln's cannon from a three hundred year oblivion at the bottom of the sea, will be making her way out to the site at Dalarö Island where another one of Sweden's great dreadnoughts, the royal warship Riksäpplet, sank to the deep with its entire array of wealth and equipment in 1676" (Stockholms Tidningen 1921, 22/8).

Countless newspaper stories were written about the history and dramatic events surrounding the sinking of the Vasa as preparations were made to salvage it in 1961 and when this was finally staged. The adventure, the drama, the remarkableness, and the great historic background were the main elements in these accounts. And again in the beginning of the 1980s we encounter almost the same "dreams" expressed on the pages of newspapers. Sydsvenska Dagbladet writes of the sinking of the Kronan on June 5, 1981: "The open lower gun ports of the Kronan were driven under the water, the sea rushing in, the ship heeling more and more, the heavy guns undoubtedly tearing themselves from their moorings on the gundeck. The disaster cul- 
minated when the powder magazine ignited and the Kronan exploded and sank in $28 \mathrm{~m}$ of water..."

A fourth example is very recent. In the evening paper Aftonbladet in May 1991 there is a description of the foundering of the ship Lybska Svan which belonged to the fleet of King Gustaf Vasa, and which was thought to have been located as a wreck in Stockholm archipelago in November 1990. The article begins with the text: "With a thunder the Lybska Svan grounds in Nämdöfjärd Bay. Scenes of horror are seen when the ship sinks with men and all. It is bad piloting which, in 1525 , becomes the fate of the flagship of Gustaf Vasa. 465 years later a diver finds the old unfortunate ship." The article then dwells in text and pictures on both the adventure and the national importance of the find (Aftonbladet 9/5 1991).

Further, in some cases the salvagers on old warship wrecks are given a heroic image. Alfred Bäckman in the daily Kalmar paper Barometern describes the wreck salvagers as "men who dauntlessly have undertaken the task to save what can be saved of the memories from the glorious battles in Kalmar Sound." He also has a vision that the salvage operations will get so much encouragement that one day it will be possible to tow "a Danish admiral's ship from the 17th century alive so to say - into Kalmar harbour. He who lives shall see," as Alfred Bäckman ends his visionary thought (Bäckman 1908-1909). This type of media images are also common in connection with the salvage operations on regal ships in more modern times - quite easy to identify in the press coverage of the Vasa and later projects of this character.

\section{NATIONALISM AND THE OLD WAR- SHIP WRECKS}

A high estimate of the national importance of the wrecks of the largest warships was eloquently expressed by Carl Ekman, the excavator of the big "kravel" Elefanten, in a series of lectures he held in the 1930s on his investigations of the ship, which sank in 1564. When he petitions for an investigation and salvaging of the ship he says: "Naturally, many people regard this matter (the investigation of the wreck) in a different light than the undersigned, but we can all agree that when we have the remains of a warship almost within our grasp, an object which without the slightest doubt is a work of the one and only Gustaf Vasa (king of Sweden 1523-1560), who was instrumental in achieving our national independence, who returned the land to us, it becomes a matter of honour for the nation that enough of these remains as possible be recovered from the bottom so that we, using these as a model, can produce a reconstruction of the ship.

No nation can reject such a treasure. It would be unforgivable, considering the aforesaid and considering the reverence which England has displayed concerning Nelson's flagship, the Victory. If one were to indulge in dreams of the recovery of the Elefanten in is entirety, its conservation and reconstruction, I for my part feel that such an undertaking is by no means impossible to realize and is worthy of as old a nation as the Swedish" (The Ekman files; The Archives of the Swedish National Maritime Museum).

The salvaging of the Vasa at the end of the 1950 s generated a wave of nationalism. A fund-raising campaign, the motto of which was "Be a Wasa saviour" (Sw. "Bli Wasaräddare"), brought in substantial sums of money to help in salvaging the ship. A medallion was sold and on one side were the words "Wasa - The King's Regal Ship".

The salvaging itself attracted a large audience. Thousands of people followed the operation from the shore and from boats and ships, along with millions of television viewers. The site was also visited by members of the Swedish royal family and by a number of official, distinguished guests.

Both the currency of a country and its stamps are often used to express characteristic or outstanding features of a nation. The na- 
tional importance of the Vasa and the Vasa project has later been emphasized, for example, by the appearance of the ship and some of its carvings on the Swedish 100 crown bill, and it has also been used on several occasions on Swedish postage stamps (Fig. 5).

Just a short time after the salvage of the regal ship Vasa a naval flag was donated to the Vasa committee by the king. This event took place on the Swedish National Day. The flag soon was and still is hoisted on the stern of the ship (Fig 6 and 7).

In March 1991 the find of a wreck was introduced which was thought to be one of the ships in the first navy of Gustaf Vasa, the Lybska Svan. Very similar evaluations as those presented by Ekman 60 years earlier in connection with the work on the Elefanten, built under the same king, were presented in TV and press interviews by the persons marketing the new find. By quoting the daily paper Svenska Dagbladet on March 26, 1991, one gets a picture of the story delivered: "After a three year search a group of divers has found what in a sense is the cradle of the Swedish nation, the flagship of Gustaf Vasa, the Swan, which sank in the northern part of Nämdöfjärden bay in the Stockholm archipelago in 1525 . On board the ship were held the capitulation negotiations with the defeated Danish king Kristian II, "The Tyrant," and in the same cabin was signed on the 17th of June 1523 the letter which made Stockholm the capital of Sweden.

"The ship is the world's oldest, reasonably well-preserved ship and the find an international sensation, which due to its historical importance in a marine archaeological perspective widely outshines the Vasa and the Kronan ships... Nowhere in the world has a ship of corresponding historical importance been found, and... what one now has found is the most outstanding national monument. The ship itself is the cradle of a nation. It was in her cabin that Sweden was united."

\section{ROYALISM AND THE WRECKS OF OLD WARSHIPS}

The distance from nationalism to royalism is short, the two concepts are in many ways two sides of the same thing. The term "regal ship" (Sw. Regalskepp, realskepp, royalskepp, reijalskepp) was used within the Swedish navy during the first half of the $1600 \mathrm{~s}$ to define the biggest ships of the navy. "Regal" has several meanings. One is "royal," or "belonging to the king or Crown," another is in a more general sense "big or splendid" (SAOB and Halldin 1964: 80). Both meanings are applicable to the regal ships which were the biggest ships belonging to the king's navy. Another aspect is that "regalier" in Swedish means "the insignia of royalty." Not seldom have the biggest ships of the navy borne names of the royal insignia, such as Riksäpplet (The Orb), Kronan (The Crown), Svärdet (The Sword), etc. In other words, the concept of the big warships was and still is closely connected with kingdom and its insignia of power. In our time "regalskepp" has come to mean the big warships from the 17th century whose wrecks have been subject to salvaging or investigation.

The male individuals of the Swedish royal family have long since had a strong interest in the navy. This goes back to the time of the sailing fleet. Nearly all of the young royal princes in later generations have been given education and training as naval officers. This, of course, is originally due to the roles of the male royal persons as commanders or members of the officers' staff of the fleet in the early days. The connections between the activities around the wrecks of old warships and royalty in our time have taken two different forms especially. To start with, it is very common that in popular, historical descriptions of the old ships, their fates, and the wrecks of them the king to whose fleet the ship belonged plays a prominent role. Old regal ships and other warships subject to salvaging or investigation have usually 


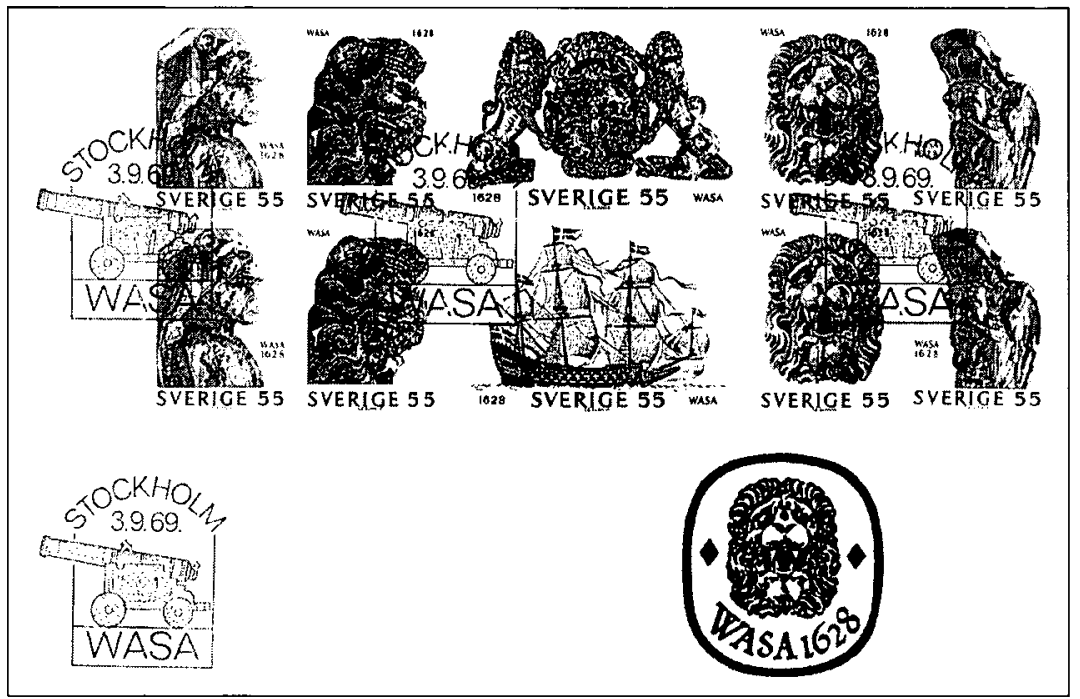

Fig. 5. One set of Swedish stamps, commemorating the regal ship Vasa, introduced in 1969.

Photo: The Vasa Museum.

been described as closely connected with the kings' reign when the old ships were still sailing. The ships are described as illustrious parts of the fleet of the mighty kings. The former are often described as playing important roles in the political and military dealings of the kings.

Swedish royalty of later times is also strongly connected with the concept of the old royal warship in the respect that royal persons have appeared in many roles interacting with the ships or the remains of the ships. This is something which one can follow during the whole period from the middle of the 19th century and onwards. When the Vasa was prepared for salvaging, one was, for example, careful to mention the positive support and encouragement given by King Gustaf VI Adolf. The royal prince Bertil was elected the chairman of the board of the Wasa committee preparing the salvaging of the ship. When the Kronan was located in 1980 the present king, Carl XVI Gustaf, was declared to have a keen interest in the find and he also visited the site. The king is also the patron of the Kronan Foundation. He inaugurated the new Vasa Museum when it was opened in 1990. When the so-called Lybska Svan was located in 1991 the congratulations of the
Swedish king were forwarded to those who had made the find via the TV news on the evening of the presentation of the find.

Royal persons have many times inaugurated exhibitions of finds from the old warships. The former Swedish king, Gustaf VI Adolf, a trained archaeologist, visited the excavation of the Vasa in 1961 in full field equipment. The present king, Carl XVI Gustaf, a trained scuba diver, has not only dived on the site of the Kronan but also on the Riksäpplet.

Another expression of the royal connections can be seen in the minting of saviour or memorial coins for the financing of the projects to salvage the big ships. As mentioned earlier, in the 1950s a medallion was created to sponsor the Vasa project, with the words "Wasa - The King's Regal Ship" inscribed on one side. When support was sought for the Kronan project in the 1980 s one used an advertisement in the campaign to raise money for the excavation of the wreck. The text stresses the royal connection of the issue with the words: "with the benign permission of His Royal Highness The King we mint a commemoration coin with the portrait of the king and with the regal ship Kronan on the back side."

Publications on the regal ships under 


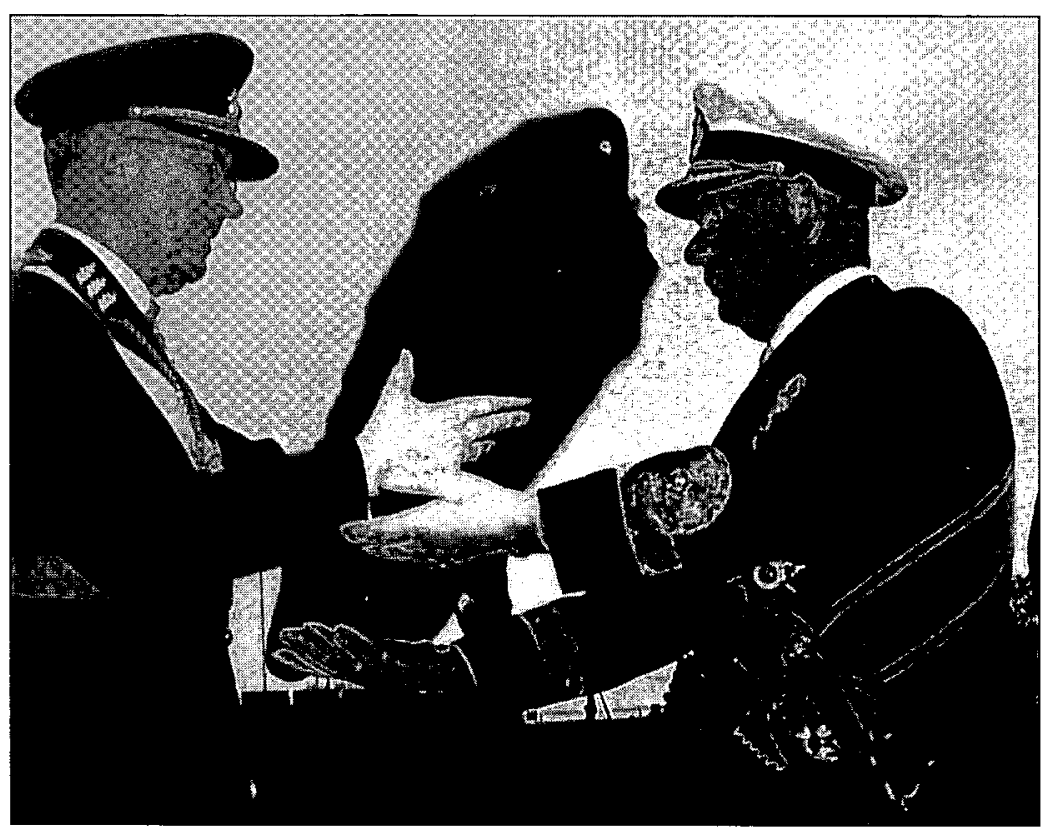

Fig. 6. The Swedish naval flag was donated to the Vasa Committee on the Swedish National Day, the Day of the Swedish Flag, the 6th of June 1961. The event took place just a short time after the raising of the regal ship Vasa from the bottom of Stockholm harbour. In the photo one of the members of the board of the Vasa committee vice admiral Gunnar Jedeur-Palmgren - is receiving the flag from king Gustav VI Adolf. Photo: The Vasa Museum.

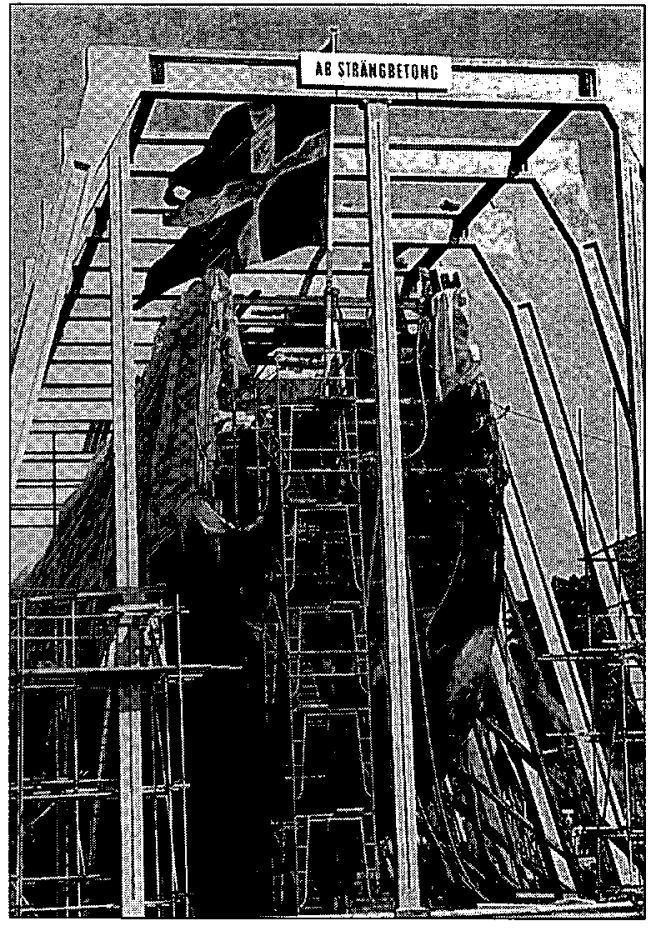

Fig. 7. The Swedish naval flag flying from the stern of the regal ship Vasa in the summer of 1961. Photo: The Vasa Museum. investigation have often an introduction by the king or a royal prince. This can be exemplified by books presenting the Vasa and the Kronan (Franzén 1974 and Johansson 1985). Both of these publications are introduced by members of the Swedish royal family: Prince Bertil, a certified naval officer himself, introduces the book on the Vasa, while King Carl XVI Gustav, also a certified naval officer and formally the commander of the navy as well as a full admiral of the Swedish navy, introduces the book on the Kronan.

One interesting aspect of the royal connection is seen in the spread of artwork craft and souvenirs of "black oak" made from ship timbers of the old warships. Several times since the 1860s such relics have been given as gifts to royal persons. When black oak was salvaged from the Nya Riga in Karlskrona in the 1860 s, such a gift was produced, according to a note in a daily paper: "A whole set of furniture was specially manufactured for King Karl XV, who found the furniture "very fine" (Barometern 1/7 1909). In an article in Stockholms Tidningen on the 27th of Sep- 
tember 1921 one mentions that Queen Victoria is said to have a set of furniture manufactured of black oak taken up from a wreck in the Sound (this could possibly be the same set that belonged to the royal family).In an article in the weekly "Se" of September 1964 on the salvaging of black oak from the Vasa (II) at Djurhamn in the 1960s, the salvager tells that even the king (Gustaf VI Adolf) has "at home in his castle one holder for salt and one for pepper, manufactured of black oak" from this ship. According to the article, he had seen the objects at a dinner to which he was invited and had been so pleased, that the objects immediately had been presented to him as gifts ("Se" 10/9 1964).

In the VIP department of the community swimming hall in the town of Södertälje there is mounted a part of the ship's side of the Vasa (II), salvaged from the wreck at Djurhamn in the 1960s. On it is a silver plaque commemorating the royal ship, with the personal signature of king Carl XVI Gustaf.

In other words, relics of black oak from the old warships were not only produced for a long time; such relics were also given to royal persons, or royal persons were asked to "bless" them by signing or introducing them to emphasize symbolically the connection between the old warship and royalty.

What has been described here are just a few examples of actions and situations which connect present-day Swedish royalty with the remains of the old royal warships. There exist many more in our society.

\section{THE BEARERS OF NATIONAL MYTHS} The officers of the Swedish navy are quite often seen as a conservative group in society. In earlier times the naval officers often were recruited among the upper classes, and in the 19 th century and earlier many of them were of noble birth. This, of course, reflects an old system of class privileges in which officers, especially those of higher rank, often were noblemen and thus belonged to the upper classes. Even if all the naval officers a hundred or a hundred and fifty years ago were not of noble ancestry, many of them came from well-to-do families. The latter often considered the training as a naval officer as a good preparation for any career and let their sons undergo this training to become officers in the reserve.

It is evident that several persons in the navy or connected with the navy since the beginning of the 19th century have been interested in various ways in the wrecks of the old warships and their history. Examples of this have been given above. It also seems evident that representatives of the navy over the span of time uphold a common tradition in which the value of and interests in the remains of old warships of the great era are a vital part. This may be exemplified by the fact that through the generations they work on the elucidation and explanation of the same royal warship wrecks of high age, and are interested in similar aspects of them. For example, the salvaging of old guns as artefacts and symbols has been one main objective for all projects of this character more or less. Also, the same ideas and initiatives appear. For instance, the salvaging company working on the site of the Riksäpplet in 1921, in communication with Commander Lennart Stackell, introduced the plans to salvage objects from or even lift the Vasa (I) from the bottom of Stockholm harbour already at this time. The project could not be continued (see above) and the salvaging was instead realized through the initiative of another representative of the same tradition, Anders Franzén, in collaboration with naval officers, technicians and others a generation later.

Seen in this perspective, one may look upon the naval officers engaged in the preservation of the memory of the big royal warships as the descendants, or the followers, of the officers of the old society, who came from the ruling classes, stood closest to the king and the establishment, and had similar interests in naval affairs. 
NAVAL HISTORY AND ITS ROLE AS PART OF THE NATIONAL MYTHS

One can discern a very strong interest in the history of the navy on the part of its own representatives even long before the salvagings and investigations of old warships wrecks. This is evident during the period in which the big sailing warships were still in use but also after that. It is best exemplified by different works on the history of the navy. About a dozen works on the history of the Swedish navy have been published since the early 18 th century (see for example Bechstadius 1734; Bäckström 1884; Gyllengranat 1840; af Trolle 1868; Munthe 1921; Hägg 1910).

These history books are usually written by naval officers, or by others under the supervision of naval officers. In the publications one finds all the evaluations evident in connection with the activities around and the presentations of the old warship wrecks since the middle of the 19th century. The latter interest is, in other words, a projection of the navy's old interest in its own history.

The publications on the history of the navy are often dedicated to the king or a royal prince under whose protection the same were written. Several of the naval history books are written in a popular form and written for the young members of the navy for their own enlightenment. Especially the later publications, from the period around the turn of the century, emphasize clearly the need to strengthen the navy and the sea defences of Sweden. This is evidently a part of a political battle for the development of the navy around the year 1900. In this battle naval officers were active together with conservative politicians and conservative organizations. It is thus no coincidence that two Swedish prime ministers in the early 20 th century were admirals - Fredrik Wilhelm von Otter 1900-1902, and Arvid Lindman 1906-1911 and 19281930.

The history of the navy presented in the publications is concentrated on the roles of the kings in political and military developments; the famous naval battles; the heroic officers and the big sailing warships, and the roles of these in the battles; the adventure and drama. They are usually very nationalistic presentations, aiming at the support of the establishment. Some of the presentations begin with the Viking Age and panegyric presentations of the Viking as a courageous hero with a strong fighting spirit. He is the forefather of the naval hero in later periods. The medieval period is seen as a less glorious period, while the history of the reign of Gustav Vasa in the early 16th century seems to start a great age of naval warfare lasting for 300 years.

The earliest of these naval history books is the most interesting. It was published in 1734 and bears a long title translated below. It was written by the vicar of Vissefjärda parish in the county of Småland, C.N. Bechstadius, and it was published after having been supervised by two naval officers and two state officials (Bechstadius 1734). The treatise bears the title: "The noble and learned Swedish sailor; That is:

I. A List of Swedish Nobility, which have their origin from sailors.

II. A List of some Naval and Admirality gentlemen and officers, who have made themselves known through Learnedness and Studies, to which is appended some other spectacular things concerning Royal Swedish Naval Affairs, to the service of The Youth of the Royal Swedish Admirality."

In the publication there is a treatise on the noble character of the Swedish sailor and naval war hero, which is very interesting in itself and worth a separate study. The last part of the book deals with "Some Remarkable Events Involving Swedish Ships."

In this one finds short, dramatic descriptions of the last voyages or battles or the founderings of famous Swedish naval ships of the 16th and 17th centuries, such as:

- the loss of the Svanen in 1524. (The wreck has been searched for during several decades 
by Anders Franzén and others in our time, and it was thought to have been located in 1991.)

- The loss of the Elefanten in Kalmar Sound in 1564. (The wreck was located and investigated by Carl Ekman in the 1930s.)

- The loss of the Vita Örn. (The wreck has not yet been located.)

The loss of the Vasa in Stockholm. (The wreck was located in the middle of the 19th century, possibly in the early 1920s and in 1956, and it was salvaged in 1961.)

- The loss of the Västervik in Stockholm in 1676. (The wreck was possibly located and salvaged from in 1896.)

- The loss of the Kronan east of the island of Öland in 1676. (The wreck was located by Anders Franzén in 1980 and is since then under excavation.)

- The loss of the Riksäpplet in Stockholm archipelago in 1676. (The wreck was located and salvaged on in the 1860 s, as well as in the 1920s, the $1950 \mathrm{~s}$ and also later.)

- The loss of the Riga in Karlskrona in 1717 by fire. (The wreck was located and salvaged on by naval divers in 1867 .)

In other words, already in the early 18 th century, about 250 years ago, there existed not only a documented interest within the navy in its own heroes and their deeds. There also existed a documented interest in the adventures and dramatic losses of some of its big ships. One may see this as a body of naval lore existing in connection with the spread of information about the navy in order to strengthen the morale within the navy and its role in society. In the list given earlier in this paper on salvage operations on warships wrecks, one can see that many of the wrecks of famous naval ships on which salvaging and investigation were conducted in the last 150 years - especially by navy personel - were of interest to the navy already in the early 18 th century.

\section{THE REGAL SHIP AS PART OF HUMAN ENVIRONMENT}

Only eighteen years elapsed from the time when the last big sailing warship was taken away from the naval base in Stockholm harbour until the Vasa was raised in 1961 from the bottom of the same harbour and towed to a dock there for excavation and display for a big public. The former was the steam frigate Vanadis, built in 1862, which during her last years had been derigged and used as a store- and receiving ship at Skeppsholmen in Stockholm. She was taken away to be scrapped in 1943. Another big sailing warship far into the 20th century was moored in Stockholm harbour for similar purposes, namely, the steam corvette Freja. The Vanadis, the Freja and the Vasa were derigged as they appeared for viewers along the quays of Stockholm in the 20 th century. In that respect they had lost one of the most important features of the big warship with regard to appearance, namely, the high rigging. Up to the beginning of the 20th century the highrigged ships had been an eye-catching sight in Stockholm harbour as well as in other naval harbours. The existence of these structures in the environment was especially apparent in contemporary town environment, where the town houses usually were just a few storeys high. The only buildings matching the rigged ships in size and height a few generations ago must have been the big churches and palaces.

In other words the Swedish capital, supposedly since the end of the 15 th century and up to the first half of the 20th century, that is, during more than four hundred years, had housed in its harbour big, high-rigged sailing warships. From the 16th to the 19th century they appeared there in great number, with their masts creating a "forest" seen from a distance (Fig. 8). In the end they were represented by one or two old hulls partly or completely rigged down.

What did the presence of these big ships in the centre of the capital mean at the time? 
It seems that these ships were regular appearances in the environment of port cities or towns in Western societies in the same way and just as regularly as churches, castles and palaces. Were, and are, the high-rigged warships symbols which we "need" for similar reasons as we "need" the buildings just mentioned? The new Vasa museum has on its roof a full-scale replica of the original rig of the ship - thus making the appearance of a big, rigged warship once again part of the environment of Stockholm harbour (Fig. 9).

\section{SYMBOLIC ROLES OF THE REGAL SHIP IN SOCIETY}

The regal ship had one eminent physical role in the old time, namely, as a fighting unit at sea. In this capacity it had an influence on military and political development and consequently also on the development of the well-being or the misfortunes of the nation and of the common people. This influential role was, of course, part of the image which the regal ship projected in the minds of the people around it.

All the same, it would be wrong to say that this was its only role. Supposedly one would not have made the ship so much like a heavily adorned, palacelike structure if it was to be used only for fighting. The heavy adornment tells us that it was not only a fighting unit but also a carrier of other messages than ones of gunfire. This was the case not only at sea and during the relatively short periods of time in front of enemy ships. The messages given by the ships' appearance were directed towards their crews, which consisted on each bigger vessel of several hundred people who lived and worked on board. They were also directed towards those who saw them, when the ships were under sail along the coast or at sea, but especially when they were anchored or moored at a naval base for long periods, usually near densely populated areas like cities or towns.

Dr Hans Soop, in his works on the sculptural adornment of the Vasa, has given an excellent example of how the big warship was used symbolically during its time (Soop 1978 and 1986). During the 16th and 17th centuries prestige was the dominant factor behind ship adornment. A new national concept had developed during the 16th century, namely, the idea of the national state led by a dynamic ruler. The ideal picture of the latter had been given by the Italian author and politician Machiavelli in his book "Il principe" from 1513. Europe of the 16th century gave birth to modern national states governed by forceful rulers. In Sweden Gustaf Vasa is a good example of this type of leader.

The sculptural adornment of the Vasa can be said to have two main themes: one panegyric or glorifying, and one didactic-moralizing. The first dominates, and the motive for the panegyric message is the wealth and strength of the Swedish nation but above all of the king himself, Gustav Adolphus II. In the messages of the different symbolic structures shown in the sculptural adornment, he is uncritically glorified and raised to the sky, as one points out his magnificent qualities and souvereign position of power. The other theme, the moralizing or didactic, is aimed especially towards the crew and was supposed to strengthen the crew members' morale, courage and fighting spirit. Also in this context the king serves as a model to look up to and follow (Soop 1978: 49). A whole world of mythological figures, in the shape of wooden sculptures, are used to support these messages. Heathen and Christian personages, half-gods like Hercules, classical heroes and famous figures from the Bible and Roman history cling to the side of the sterncastle of the big ship, striving in the symbolic gestures and patterns they create to make clear the divine role of the Swedish king.

In an immaterial way, as a symbol of national strength, the regal ship is still very much alive. The regal ships in focus in Swedish society lately, such as the Vasa and the Kronan, are to a high degree images of the Swedish nation and its apprehension of its 
strength. Today it is not military strength one wants to project but instead the vigour of the Swedish society in other respects. Since its salvaging, the Vasa has for example become an important "goodwill-symbol" for Sweden and Swedish industry. The images of the ship have been used to a great extent by Swedish enterprises in connection with advertising. Many Vasa exhibitions have toured the world, often in connection with marketing and technical fairs. When heads of state visit the Swedish capital they are taken to the Vasa Museum with the regal ship standing in its middle, just as often as they are given an audience with the king or meet the prime minister (Fig 10).

The regal ship quite evidently in its time was an expression of the power of the establishment. The regal ships the Vasa and the Kronan to a high degree are expressions of the formal establishment of society also today, and are used to support the Swedish nation in several ways. This has been the case wether the nation has been governed by social democrats, conservatives or others. The latter circumstance can in turn be interpreted as an effect of the historical condition that the Swedish nation long since fosters a strong central power. The regal ship, as a phenomenon, fits well into this pattern.

\section{THE REGAL SHIP AS A ROYAL AND A DIVINE SYMBOL}

The ideas of divine kingdom emanate from the oriental, prehistoric cultures. The Pharaohs of ancient Egypt were the successors of gods which had governed the land of the Nile. The Babylonic rulers were the earthly representatives of godliness. This concept was taken into the Roman Law during the reign of Emperor Diocletianus. It was developed in the European medieval society and flourished during the Renaissance. The Christian king, like the Roman rex, became both king and priest.

The Vasa and the other regal ships of Sweden were and are ships which bear the anima of the king. This applies not only in the

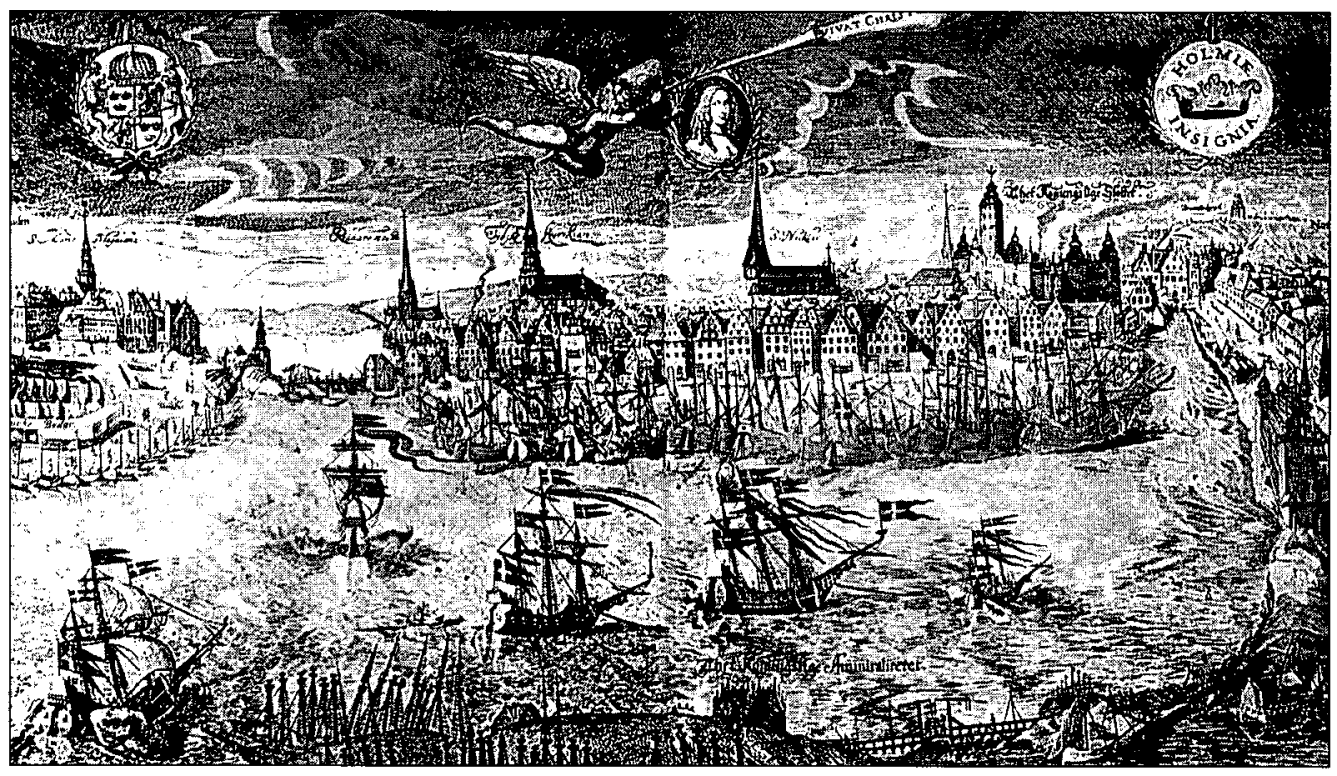

Fig. 8. An en graving by Wolfgang Hartmann from 1650 shows Stockholm and its harbour, seen from the east. It is easy to see that the artist has empha-sized three facets of the appearance of the capital. These are all big and high, man-made structures, namely the big sailing warships (in the foreground), the royal castle (to the right) and the big churches in the central part of the town. 


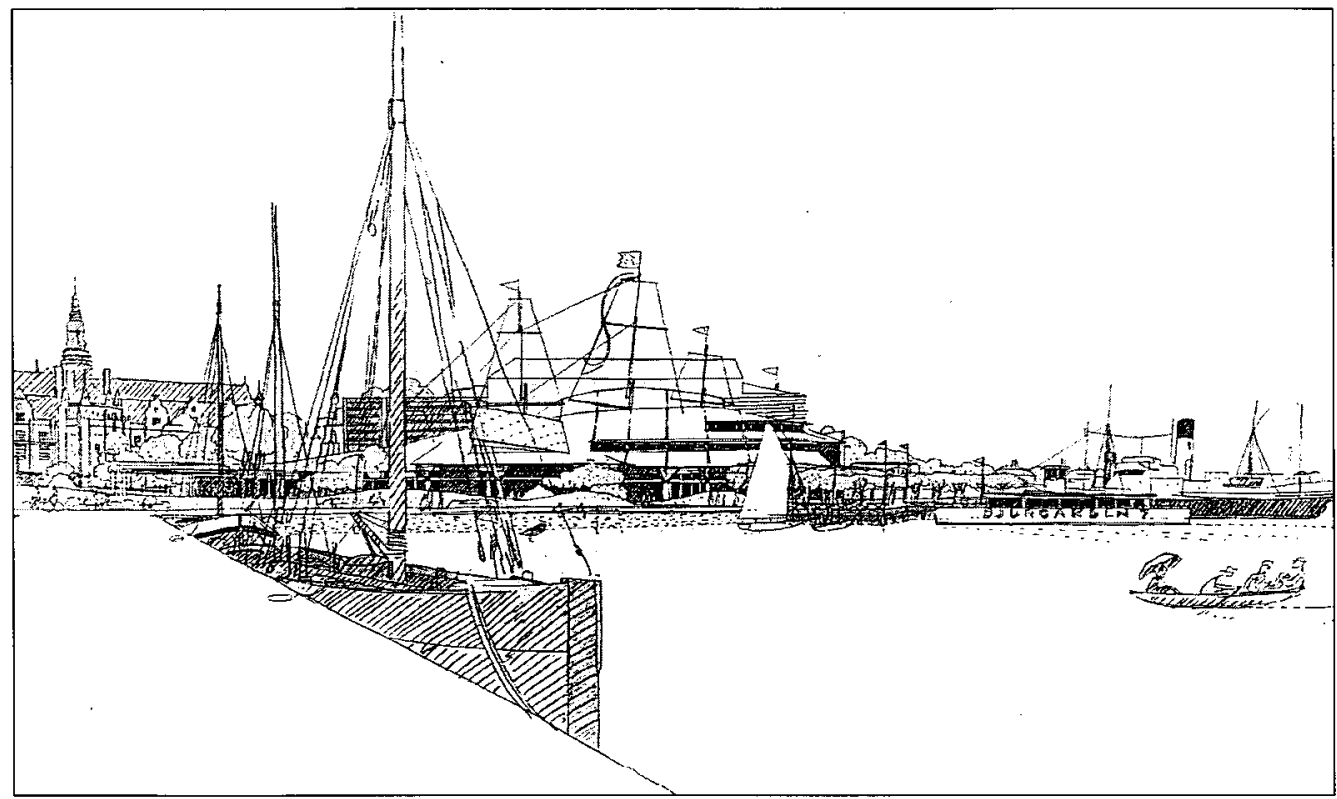

Fig. 9. Perspective drawing showing the new Vasa museum in Stockholm as it in the first half of the 1980s was projected to look in the setting of the Stockholm leasure area "Djurgarden". On the roof of the museum is raised a dummy of a big warship's rig of the 17th century. The big sailing warship was back in the harbour of the town. (Helmersson et. al. (ed.) 1985, l).

case of their exceedingly rich sculptural splendour, but also in the way in which they were and are being treated by the naval officers - "the priesthood" of the royal ships that managed and tended and fought the enemy with them, assisted by the crews under the eyes of the citizens of the country. The ship might be looked upon as a magical, animated being, which, in the case of the regal ships, is accentuated by the many carved pictures on them, for example, the figure-head of the Vasa which takes the shape of lion, representing the king.

It is appropriate to turn back to the introduction of this presentation and the list of examples of old preserved ships around the world. In the list one can find two groups of present-day memorial ships which have a strong connection with royalty and divine kingdom. One is the group which I chose to call the royal burial ships. In the examples given they are of high age, like the so-called Cheops boat, which is supposedly the burial ship of Pharaoh Cheops, a sovereign of divine rights, or like some of the Iron Age ship burials of the Nordic countries. These show that the symbolic connection between the ship and royalty reaches very far back in time. In the list of ships in the introduction there are also the royal or state warships, of which Swedish examples have been treated here. Among these are ships from both prehistoric and historic times.

It is important to emphazise the fact that old ships, preserved as symbolic expressions in our time, were also used in symbolic functions several thousand years ago. It is also important to stress the fact that in early times as well as today the ships were and are saved and displayed in a way which shows strong symbolic functions in relation to divine kingdom. According to the account given previously in this treatise, the royal ship and divine kingdom seem to be very active and strong symbolic expressions in present-day society as well. It is also important to state 
that the success of the presentation of old royal warships in our time is to a great extent in my view due largely to the fact that the presentation is based on an age-old concept. This concept, ground through millenia into the pattern of our society, is that of the royal ship as a representative of the king of divine rights.

\section{THE DREAM OF THE REGAL SHIP} RESURRECTED AND ITS REALIZATION The salvaging of the Vasa in 1961 was not the "deus ex machina" event it seemed to many. On the other hand, the idea to salvage one of the old royal warships and present the ship and the greatness of naval history it represents, had been fostered among the representatives of the traditions of the navy for at least two or three generations. It appears in one of Bäckman's rather panegyric articles in Barometern on the Enighed in 1909, in which he has a vision of the old Danish ship being towed into the harbour of Kalmar (like the Vasa was towed into a dock in Stockholm harbour fifty years later). In 1921, in connection with the salvaging on the wreck of Riksäpplet, one discussed the possibilities to salvage this ship. Among other things there was a plan to salvage a big part of one of the ship's sides which measured about 30 sq. metres, "in order to acquire the best possible illustrative material to answer questions about the Riksäpplet's construction and design (Dagens Nyheter 10/9 1921). One also discussed the possibilities to salvage the wreck of the Gröne Jägaren, on which some salvaging had been done at this time. This ship was considered to be more well preserved than the Riksäpplet (Dagens Nyheter 28/10 1921; Svenska Dagbladet 29/10 1921). At this time it seems that the salvagers also had far-reaching plans to salvage the Vasa (I) in Stockholm harbour (Stockholms Tidningen 22/8 and 25/8 1921), which was considered to contain rich finds not least of bronze guns.

In the 1930 s and also later Ekman expresses his wish to see the Elefanten salvaged as a monument of naval history (The Ekman files, SSHM Archives). Part of it was, in fact, salvaged and displayed in the National Maritime Museum in the $1930 \mathrm{~s}$, although it was done piece by piece. This dream of resurrection lives on also after the salvaging of the Vasa in 1961. The Kronan project of today includes plans to salvage a considerable part of this royal warship for exhibition in Kalmar (pers. communication from Lars Einarsson, Kalmar County Museum). Perhaps the resurrection act described here is basicly "holy" in character, holy in the respect that it is a strong ideological expression.

Seen in an ideological perspective, it is a victory for an influential group in society to see the Vasa salvaged, restored and exhibited in the Vasa Museum, recently designed and erected. One could call the engagement in society described here as an ideologically and supposedly also politically conservative movement. At least it seems to have a definite, conservative message for society. Also in the perspective given here it is of interest to note that the group or movement refered to here, after the opening of the Vasa Museum, is now working towards developing the area around the museum into what is called a "Center of Maritime History", in reality a "Center of Regal Ships." The aim is to incorporate other ship remains of the same category, for example, finds from the Kronan and the remains of the ship which was introduced as the Lybska Svan. This approach in turn seems to be integrated into a more far-reaching plan, including the development of a center for the same ideological/historical ideas at the present main base of the Swedish navy in the town of Karlskrona, and at the Naval Museum there.

AN ALLEGORY ON THE ROLE OF THE OLD, ROYAL WARSHIPS IN PRESENTDAY SOCIETY

Let me end with an allegory based on the theme presented here. The regal ship Vasa is located today in a templelike building 
geographically and socially in the centre of an area in the capital with a strong connection to the history and the myths of the nation (Fig. 10). It is the former main base of the royal navy on royal grounds (Djurgården) which belonged to the kings already during the time of the big sailing warships. The Vasa museum neighbours are the nearby Nordic Museum and the open-air museum Skansen. The former museum was erected around the turn of the century to commemorate and house relics of Swedish folk culture, which is also the objective of Skansen. The Nordic Museum is a large, churchlike building with a big central hall, very similar to the nave of a church. In the centre of this thrones a giant, Buddha-like sculpture of King Gustaf Vasa (1523-1560), founder of the royal family Vasa, whose grandson King Gustav Adolphus II built the Vasa. The Nordic Museum for a long time also exhibited the collections of the Royal Armory in the "nave" of the museum. These collections have now been transfered to the royal castle of Stockholm. Outside, at the front entrance, another Vasa king, Karl X Gustaf (1654-1660) sits astride his horse expressing the martial qualities of a king in his appearance and gestures.

In the Vasa museum the evaluation system of the old society and the symbols of this are shown on the walls, in arrangements and in texts to people of today. This can be compared with the way in which symbolic messages were shown, for example, in the wooden carvings adorning the big ships when these were afloat at the naval jetties in Stockholm. In the centre of the big temple-like museum hall rests the old royal ship, restored as far as possible to its original state.

It may not be a coincidence that another old regal ship under investigation - the Kronan - is exhibited in a museum near the old royal castle in the town of Kalmar. For a long time this town was second in importance after the Swedish capital, not least in naval strategy. The present royal castle was erected by the kings of the early period of the Vasa family, when the activities of the regal ships flourished.

These are two settings in present-day society in which the pattern of old society is very clearly exposed and also still fully alive in several respects. One can see that the salvaging, the investigations and the placement of the big regal ships, several hundred years old, in the center of society is accompanied by or integrated into a pattern of timebound, ritual events - part of the cultural expressions of our society. To start with, one can see that the care of the memory of the old regal ships has been managed by the group of people which had the responsibility for them when they were in use - namely, the naval officers. They have very actively preserved and presented the memories and the roles of the vessels for the people in historical commemorations of different types during at least three centuries.

In the last 150 years, when divers and diving equipment have been part of the organization of the navy, naval officers and divers have organized diving and salvage operations on the remains of regal ships. In this way they have "touched" the old royal warships and have also had the possibility to lift objects of symbolic value to the surface. These objects reveal the importance of the old ships and their roles in the old society to the general public of later times. One very common type of object salvaged is the guns of the old ships, which greatly symbolize the strength and power of the ships and their master - the king.

This has been done under the benevolent auspices of the kings and royal princes of later times. Royal persons have often visited the sites of the ships, inaugurated presentations or exhibitions of them, and protected written information about them. On several occasions royalty has received gifts from the salvagers, made from the oak of the old ships to commemorate the strong link between the two power symbols. One may see these gifts as offerings given by the priesthood of the 


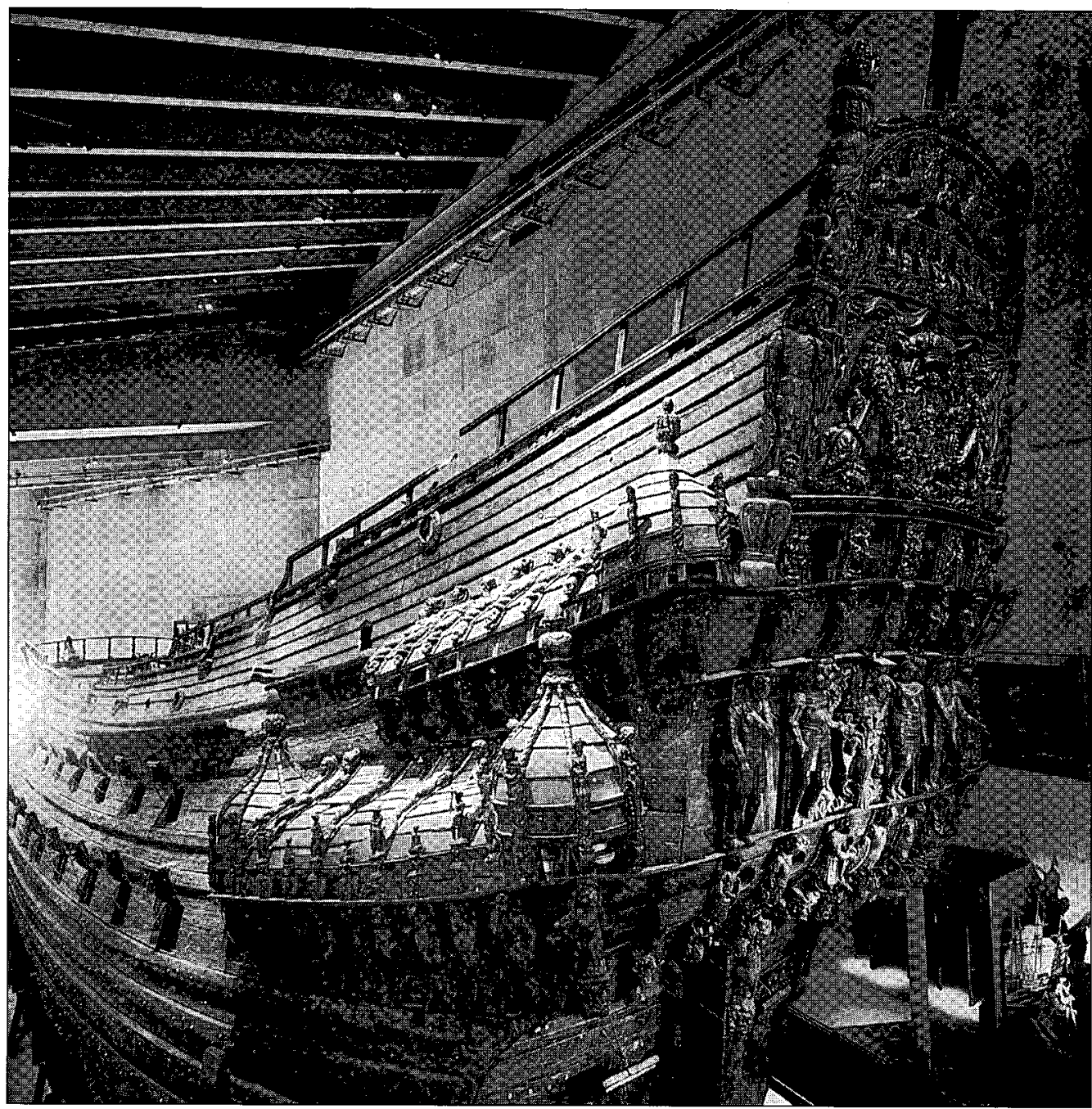

Fig. 10. The resurrected regal ship Vasa in the museum hall built over one of the docks in the former naval base of Stockholm. Photo: The Vasa Museum.

regal ships to the king, the representative of God.

One may note another "symbolic" expression of the importance of the regal ship in society, expressed by the formal part of society, the executors of law: the only times when an old wreck has been specially protected as an underwater cultural resource with the help of the Ancient Monuments Act, it has concerned the wreck of a regal ship. One may, if one wants to, see this as a way to "sanctify" the sites of the old royal ships.
It is important to note that the salvagings and other procedures referred to here have been happening with a surprising regularity. Looking back on the last 150 years, one can see that they appear quite regularly about every tenth year. Without stretching this line too hard, one can very well define the events described as a ritual, deeply embedded in Swedish society - a ritual appearing regularly and with a strong nationalistic message, built around the regal ship as a symbol of the power of divine kingdom. 
The ritual of commemoration of the royal warships has often been performed by naval officers, who have published books on the history of the same, established museum collections with models and paintings of them, and organized diving and salvaging on them. The spread of information on the wrecks of old warships in later times has been done by daily papers, not least the ones with a conservative outlook, in a surprisingly uniform way. The same elements as in the 200 year old history books of the navy recur time after time in the more recent presentations of the results of salvaging or underwater investigations of the old wrecks. The elements have been described above: the highlighting of the roles of kings in connection with the wars and battles the ships fought; the heroes and the dramas and adven- tures in which they acted; and the mighty weapons and treasures on board the ships.

If we could see our own time and society as a fragmentary pattern, glimpsed through sources of different kinds - rifts in the time web - in the way we see the past within archaeological or historical studies of the humanities, wouldn't we see a society in which divine kingdom is a very active part?

It might be of interest to try to trace the symbolic themes connected with the royal warship, which are visible in society during the last 300 or 400 years, back in time. The objective would be to try to see in what ways and to what extent the very active ship symbolism of later centuries connects with the ship symbolism which is seen as an important part of Nordic, prehistoric and iron age society by archaeologists.

\section{REFERENCES}

\section{Unprinted sources}

Lunds Historiska Museums Arkiv (Archives of the Historical Museum of Lund University)

Svensk Marinarkeologiskt Arkiv (SMA). Statens sjöhistoriska museum, Stockholm. (Swedish Marine Archaeological Archives, Swedish National Maritime Museum, Stockholm)

Statens Sjöhistoriska Museums Arkiv. (Archives of the Swedish National Maritime Museum, Stockholm.)

\section{Printed sources}

Aftonbladet. 1991. Stockholm.

Baker, W.A. 1958. The New Mayflower. Barre, Mass.

Barometern. 1908-1909. Kalmar.

Bechstadius, C.N. 1734. Den Adelige och Lärde Swenske Siö-Man; Thet är I. MATRIKEL öfwer Sweriges Ridderskap och Adel, whilka uthaf Siö-Män hafwa theras uhrsprung. II. Förteckning uppånågra Swenska Siö-och AmmiralitetsHerrar och Officerare. Stockholm.

Brouwer, N.J. 1985. International Register of Historic Ships. Over Wallop, Hampshire, England.
Bäckman, A. 1908-1909. Articles in the daily paper Barometern, Kalmar.

Bäckström, P.O. 1884. Svenska Flottans Historia. Stockholm.

Cederlund, C.O. 1983. The Old Wrecks of the Baltic Sea. Archaeological recording of the wrecks of carvel-built ships. BAR International Series 186. Diss.

- 1988. Museet och marinarkeologin - ett historiskt perspektiv. Sjöhistorisk Årsbok 1988-1989. Borås.

Christensen, A.E. 1986. "Viking", A Gokstad ship Replica from 1893. In: Sailing into the Past. Proceedings of the International Seminar on Replicas of Ancient and Medieval Vessels, Roskilde, 1984. Århus.

Crumlin-Pedersen, O. \& Hartvig Nielsen,T. 1965. Til sös med vikingeskibet "Imme Gram". $C N$ Post. Februari 1965.

Dagens Nyheter. 1921, 1982. Stockholm.

Dudszus, A. \& Henriot, E. 1986. Dictionary of Ship Types, Ships, Boats and Rafts under oar and sail. Bath.

Encyclopaedia Britannica. 1910-1911. 11th Encyclopaedia Britannica. 
Flaggan upp. En framställning af svenska örlogsflottan förroch nu. 1902. (För Kvinnoförbundet för Sveriges sjöförsvar). Stockholm.

Fliedner, S. \& Pohl-Weber, R. (eds.) 1962. The Cog of Bremen. No 35. Pamphlets of the Focke Museum, Bremen.

Franzén, A. 1974. The Warship Vasa. Deep Diving and Marine Archaeology in Stockholm. Stockholm.

Green, J. 1980. Europeans in the East (1498-1798). In: Archaeology under Water. An Atlas of the World's Submerged Sites. (Ed. K. Muckelroy).

Greenhill, B. \& Hackman, J. 1986. The Grain Races. The Baltic background. Chichester.

Grönstrand, L. 1980. Sigyn. Utg. av Åbo Akademi. Helsingfors.

Gyllengranat, C.A. 1840. Sveriges SjökrigsHistoria i sammandrag. Carlskrona.

Hafström G. 1961. A.L. Fahnehjelm och skeppet Wasa. Tidskrift i Sjöväsendet. Vol. 124.6. Juni 1961.

Halldin, G.(ed.) 1964. Svenskt Skeppsbyggeri. Malmö.

Helmersson, K., et. al. 1985. Ett nytt museum för Wasa. Utställningsprogram. Statens sjöhistoriska museum. Stockholm.

Heyerdahl, T. 1948. Expedition Kon-Tiki. Stockholm.

Hillbom, R. 1975. Chapmans efterföljare C.D. Pettersson - O.E. Carlsund - C.A. Lindvall. Aktuellt från Föreningen Marinmusei Vänner $i$ Karlskrona.

Hägg. E. 1910. Örlogsflottan. Några ord till gammal och ung om vår första försvarslinje. Med ill, av amiral J. Hägg. Stockholm.

Johansson, B.A. (ed.) 1985. Regalskeppet Kronan. Stockholm.

Kemp, P. (ed.) 1979. The Oxford Companion to Ships and the Sea. St. Albans, Herts.

Lenk, T. 1938. Kungliga skonerten Amphion. Land och Folk. Årg. 1.

Lilliehöök, H. 1909. Minnesteckning öfver Fredrik Henric af Chapman. Teknisk Tidskrift.

Lindvall, C.A. 1908. Fredrik Henrik af Chapman.
Några tillägg till hans lefnadsteckning. Teknisk Tidskrift.

Miller, E.M. 1978. U.S.S. Monitor. The Ship That Launched A Modern Navy. Annapolis, Maryland

Morrison, J.S. \& Coates, J.F. 1989. An Athenian Trireme Reconstructed. B A R International Series 486. Oxford.

Munthe, A. 1921. Sjömaktens inflytande på Sveriges historia. Stockholm.

Nordlinder, G. 1988. Sjöhistoriska Museet 50 år. Sjöhistorisk Årsbok 1988-1989. Borås.

Rieck, F. \& Crumlin-Pedersen, O. 1988. Både fra Danmarks oldtid. Skjern.

Rule, M. 1982. The Mary Rose. The Excavation and Raising of Henry VIII's Flagship. Rugby.

Rönnby, J. Det Stora Skeppet. Fartygsbyggeri och maktideologi $\mathrm{i}$ början av den nya tiden. StockholmArchaeological Reports, Nr. 25, 1992.

Se. 1964. Stockholm. (Weekly paper)

Smith, R.C.1988. The Voyages of Columbus: the Search for His Ships. In: Ships and Shipwrecks of the Americas. Ed. G.F. Bass. London.

Soop, H. 1978. Regalskeppet Wasa. Skulpturer. Göteborg.

- 1986. The Power and the Glory. The Sculptures of the Warship Wasa. Uddevalla.

Steensen Steen, R. 1961. Fregatten Jylland. Odense.

Stockholms Tidningen. 1921. Stockholm.

Sundlöf, J. 1978. Dykning. Utnyttjande och säkerhet. Stockholm.

Svensk Uppslagsbok. 1937. 1929 edition.

Svenska Akademiens Ordbok (SAOB), 1898-.

Svenska Dagbladet. 1921, 1981, 1991. Stockholm.

Thorseth, R. 1986. "Operation Viking". In: Sailing into the Past. Proceedings of the International Seminar on Replicas of Ancient and Medieval Vessels, Roskilde, 1984. Århus.

Trolle af, H. 1868. Svenska Flottan, dess minnen och öden från äldre tider intill våra dagar, tecknade $i$ sammandrag for Ungdomen och Folket. Stockholm.

Widding, L. 1961. Ombord på Wasa. Stockholm. 
. 